\title{
Causal Modelling of Failure Fears for International Entrepreneurs in Tourism Industry: A Hybrid Delphi - DEMATEL Based Approach
}

\author{
Shide Sadat Hashemi ${ }^{1}$ \\ ${ }^{1}$ Executive Manager, Saramadan Andishe Avina Co. \\ Science and technology park \\ Tarbiat Modares University, Tehran, Iran \\ consultant.mgg@gmail.com \\ Hannan Amoozad Mahdiraji ${ }^{2,3 *}$ \\ $2,{ }^{*}$ Leicester Castle Business School \\ Faculty of Business and Law, De Montfort University \\ Leicester, United Kingdom (corresponding author) \\ hannan.amoozadmahdiraji@dmu.ac.uk \\ ${ }^{3}$ Faculty of Management \\ University of Tehran, Tehran, Iran \\ h.amoozad@ut.ac.ir
}

Mostafa Azari ${ }^{4}$

${ }^{4}$ Faculty of Management

University of Tehran, Tehran, Iran

mostafa.azari@ut.ac.ir

Seyed Hossein Razavi Hajiagha ${ }^{5}$

${ }^{5}$ Department of Management

Khatam University, Tehran, Iran

h.razavi@khatam.ac.ir 


\title{
Causal Modelling of Failure Fears for International Entrepreneurs in Tourism Industry: A Hybrid Delphi - DEMATEL Based Approach
}

\begin{abstract}
Purpose. This paper aims to recognise and identify fears of failure in the international entrepreneurship ecosystem and find the effects of these fears on each other to reduce these increasing effects and minimise the mental barriers for potential entrepreneurs. Therefore, this research is beneficial to strengthen international entrepreneurial personality and to reduce the shadows of fears on entrepreneurs minds. To address this purpose the international tourism industry has been investigated in the emerging economy of Iran.

Design/methodology/approach. This paper is organised based on experts' opinions, then factors are identified by literature review and are finalised through the Delphi method with a panel of practical and academic experts. These fears are categorised using a questionnaire and factor analysis (FA) technique. The respondents were entrepreneurship students and tourism entrepreneurs. Subsequently, the effect and importance of fears of failure are scored and ranked by some experts. These fears were analysed through Decision making trial and evaluation laboratory (DEMATEL) method. The results presented the effects of fears of failure in the international entrepreneurial in the tourism industry and the relationship amongst them.

Findings. The first two fears are respectively "fears of future" which are caused by the unclear situation; and "fear of losing credit" that is due to the importance of " personal relationships" in Iranian culture. As pointed out by results, "fear of future" is the most effective group of factors that may lead to other fears too. This fear seems important in the international entrepreneurial tourism industry because of future ambiguity.

Originality/value. This study indicates the relations between groups of fears and offers some practical and applicable solutions to reduce these effects. To the best knowledge of the authors, analysing the relationship between fears amongst the entrepreneurs has not been investigated previously.
\end{abstract}

Keywords. International Entrepreneurship; Multi-Criteria Decision Making (MCDM), Fear of Failure (FoF), Delphi method, DEcision-MAking Trial and Evaluation Laboratory (DEMATEL). 


\section{Introduction}

The growth of the population in developing countries in recent decades led to the lack of job vacancies and a higher unemployment rate. This problem persuaded the majority of the new generation to avoid looking for positions and instead run their own business and highlighted the term "Entrepreneurship" in these countries. Furthermore, the crisis period leads to more entrepreneurship because of the increased recession and unemployment rate (Jafari-Sadeghi, 2020). Recently, coronavirus added another crisis that fundamentally threatened many businesses such as restaurants, entertainment, tourism, etc. Organisation for Economic Co-operation and Development (OECD) estimates on the impact of this disease point to a $60 \%$ reduction in international tourism in 2020 (OECD, 2020). This event led to a critical crisis affecting entrepreneurs careers, minds, and professional decisions. They might have an adventure behaviour to deal with entrepreneurship problems, while they lost it due to the situation. Thus, this has created a new type of fear of failure in the recent decade. In this regard, it is necessary to identify the fears and try to treat mental injuries and reduce the impact of these fears to empower their entrepreneurial courage. Entrepreneurship is a way to find opportunities in a continuously changing environment and achieve resources to produce the products and services which satisfy the requirements that are caused by these changes (Anderson, 2002). Becoming an entrepreneur requires one to feel this need individually; in fact, it is necessary to have a self-assessment of their identity as a main and elementary factor for individuals to examine their entrepreneurial intention (Mahto and McDowell, 2018; Jafari-Sadeghi et al., 2020) and trust on themselves. According to Bosma et al., (2020) in some countries such as Japan and some parts of Europe this trust is at the lowest level and people in "India", "Saudi Arabia", "Ecuador" and "Guatemala" have the highest self-confidence to start a new business. The entrepreneurs believe that running a new business helps them to have significant control on their destination and goals, earn more money, achieve mort satisfaction and provide a revenue stream and longevity business for their family (Alstete, 2002). This phenomenon is increasingly considered by different world economies in four segments as reported by Bosma et al., (2020) and shown in Figure 1.

\section{Insert Figure 1 here}

Figure 1 denotes the number of new businesses that launched during the last two years as the highest percentage of entrepreneurship in adults from 18 to 64 belongs to the Middle East and Africa, especially to Saudi Arabia. This indicates that the moral approaches of entrepreneurs in the different global regions vary based on income level (Bosma et al., 2020). Both large and small entrepreneurial companies, despite trying to become international or stay local, are increasingly engaged in economic growth (Dana and Wright, 2009).

Entrepreneurship is a section of daily life; however, plays a role to improve the social condition (Jafari-Sadeghi, 2020; Rezaei et al., 2021). The entrepreneurs should be identified beyond the local markets and gain more market share; thus, it is essential to access the rich and attractive markets to survive. In the past, international business and entrepreneurship were two separate concepts that were aggregated via the international entrepreneurship (IE) academic field during two recent decades (Dana and Wright, 2009). Entrepreneurship is a way to search and explore the massive chances and use internal and external relations to promote local and international business. This vast relationship helps the entrepreneurs and startups to achieve new capabilities and knowledge that enables the company to concentrate on major activities. Internationalisation was assumed as a growth option that will be completed gradually over time (Onetti et al., 2012). This type of 
market share development from local to global share relies on telecommunication and technology changes (Jafari Sadeghi et al., 2019; Sukumar et al., 2019; 2020). Accordingly, today's strategies concentrate on more attractive and more extended markets, called "Internationalisation" (Sadeghi and Biancone, 2017). Many researchers suggest that entrepreneurs are able to enter the global atmosphere a while after the business sets up (Anderson, 2002). The interaction and collaboration among local experts to develop and enhance a new business is recognised as entrepreneurial behaviour which helps them to internationalise the business (Sadeghi et al., 2019). Market selection in the preliminary stages of internationalisation is the consequence of the corporate's local and internal achievements (Anderson, 2002). Although the importance of entrepreneurship and internationalisation are transparent for new businesses, many cultural, environmental, organisational, and individual factors prevent starting it.

\section{Insert Figure 2 here}

According to (Bosma et al., 2020) the fear of failure may prevent entrepreneurs from starting a new business despite their sufficient knowledge, skill, and experience. In 38 countries out of the 50 , more than half of people with the ages between 18 to 64 have this sufficiency. Moreover, according to Figure 2 in 32 out of 39 countries, less than $50 \%$ of entrepreneurs who face good chances to benefit from these opportunities may give up. This implies that entrepreneurs see themselves as entrepreneurs potentially; therefore, it occurs if they do not be afraid of failure personally. In fact, in some countries, there are suitable situations to start a new business; however, the entrepreneurs would not start it due to fear of failure. Furthermore, in some economics, this feeling is claimed at the lowest level such as the Republic of Korea with (7\%) and it is followed by some European countries like Switzerland, Netherlands, and Italy. While, in several countries, about $50 \%$ of the entrepreneurs imply that despite good opportunities, they are not eager to run a business, such as "India", "Egypt", "Jordan" and Chile due to the fear of failure. Accordingly, less than $40 \%$ of Iranian entrepreneurs claimed that factor of failures fear has prevented them from becoming an entrepreneur. This indicates that about $60 \%$ of the entrepreneurs facing good opportunities, prefer to refuse to act as an entrepreneur, leading to a high unemployment rate and loss of great ideas from initial ideas to commercialised products or services, which seems critical for economy and GDP.

\section{Insert Figure 3 here}

Based on (Bosma et al., 2020) about 10\% of adults in Iran are running their own new business, while in countries like Chile or Ecuador one-third of adults are starting a new business (see Figure $3)$. As the path from startup to mature company is a difficult procedure that approximately not all entrepreneurs meet; therefore, it is important to issue to study it to recognise and plan how to support and control this process. They should finally become stable enterprises and provide goods and services to contribute to GDP. On this account, Figure 4 reveals that the percentage of earlystage entrepreneurial activities based on revenue is placed at $10 \%$ in Iran, indicating that the impact of fears of failure on entrepreneurship activities in Iran is highly effective and the economy is not relying on entrepreneurship revenue and its proportion (Bosma et al., 2020).

\section{Insert Figure 4 here}

Considering the above, many factors affect the startup generation and their survival. They struggle to exist, as newborn enterprises. Startup status lasts temporarily and a startup should scale up as 
soon as the opportunities permit (Blank and Dorf, 2013; Szarek and Piecuch, 2018). Scholars have divided the startups into two categories including Scalable and For Sale. The Scalable startups even extend their market beyond the borders to internationalise and benefit more. Therefore, their internationalisation helps them to survive and continue. According to their role in GDP (since 2019 the value created by startups around the world reaches near 3trillion (USD) which is equal to the GDP of G7 countries (Startupgenome, 2020)), it is essential to emphasise their creation and survival procedure. One important obstacle for entrepreneurship is fear of failure according to the global valid reports such as Bosma et al., (2020), mentioned. This illustrates the important effect of fear of failure which should be restrained and moderated (Business Review, 2019). Accordingly, the desirable business achievements will come true. On the other hand, the tourism industry is a profitable business that recently has extensively emerged in the format of tourism startups. Many research works and reports suggest that the tourism industry leads to income nationally and internationally. They imply that this industry's economic contribution, directly and indirectly, has accounted for 10.2\% of global GDP in 2017 (Hong, 2018).

\section{Insert Figure 5 here}

Regardless of coronavirus, the trend always has been ascending, Figure 5 indicates the total and direct contribution of the tourism and tourism industry to the global economy 2006-2017 in trillion US dollars (Hong, 2018). However, the COVID-19 pandemic interrupted this trend, and the tourism industry received the costliest damage reported by Startup Genome in Figure 6.

\section{Insert Figure 6 here}

The pandemic has also damaged the revenue more critically in Asia as Figure 7 illustrates.

\section{Insert Figure 7 here}

Therefore, it seems very important to consider the revenue reduction in the tourism industry and especially decline in Asia income, which includes Iran as the case study of this paper as an emerging economy. This problem emphasises further efforts to empower the potential startups and encourage the probable entrepreneurs in the tourism industry to overcome the economic crisis, being a critical approach to solve the unemployment problem and start the post-crisis period by new startups' foundation. As Kuckertz et al., (2020) believed that managing the entrepreneurship problems and protecting the startups from the crisis is the fast response to a crisis and provides the further startups to survive the nation's economies. The most initial protection should be applied to encourage the potential entrepreneurs to overcome their fears and moral emotion about running a new business.

According to the latest data of the World Tourism Organization, Iran's foreign tourist arrivals faced a decline of $72 \%$ in the 1 st eight months of 2020, due to the COVID-19 pandemic. According to national news, this has caused about 5.2 billion (USD) damage to Iran's tourism industry as an emerging economy. Alongside this decline, over 1.5 million people have lost their jobs in the tourism industry during the Covid-19 pandemic (Tehran Times, 2021). This highlights the importance of developing jobs and entrepreneurship in the field of Iran's tourism, especially in the post-covid era. Regarding the failed businesses and unemployment rate of tourism activists, it seems difficult for potential entrepreneurs to launch new tourism startups. Meanwhile, many activities have struggled to improve the position of the tourism industry in Iran's economy. Despite these efforts, the crisis caused by Covid-19, and some fears of failure as a result of political 
challenges between Iran with the EU, UK, and the USA, have not significantly improved this position and even became more sensitive and weakened. In this regard, it seems very important and critical to support the tourism industry and motivate potential entrepreneurs to recreate tourism entities. For this purpose, there might be some solutions including root cause studies, barriers recognition, and motivative initiatives. Identifying the fears of failure among entrepreneurs is an effective, fundamental, and applicable research in this regard. Accordingly, the current article endeavours to identify the most effective factors and analysing their relationships on entrepreneurship called "fear of failure". This identification, analysis, and ranking are productive to protect the entrepreneurs and their further efforts from these barriers. The remainder of this paper is organised as follows. Section 2 includes the literature review and in section 3 the research methodology is presented. Section 4 investigates the case study and finally, the last two sections conclude the paper and present the contribution and implications.

\section{Literature review}

\subsection{Multi-criteria decision-making}

Multi-criteria decision-making (MCDM) techniques, which make tradeoffs between numerous conflicting factors, are usually employed to analyse barriers (Xu et al., 2020; Rezaeisabzevar et al., 2020; Jafari-Sadeghi et al., 2021). In this field, The Decision-making trial and evaluation laboratory (DEMATEL) method (Mahdiraji et al., 2019; Boudlaei et al., 2020), developed in the Geneva Research Centre of the Battelle Memorial Institute, is a useful tool to build and analyse relations between factors or barriers in complex situations (Wu and Lee, 2007; Hajiagha et al., 2018). Shieh et al., (2010) believe that this method helps the entrepreneurs to better understand the specific problem, the intertwined and interrelated factors, and have a contribution to identifying feasible solutions based on a hierarchical structure. The main advantage of DEMATEL is building the structure of a relation map as well as considering the interrelations among the factors or barriers. Besides, it not only considers the direct and indirect relationship between the barriers but also visualises the structure of the relations with direct-relation matrices.

Hence, many scholars have successfully applied the DEMATEL to identify key barriers or factors. For instance, Shen (2017) used the different perspectives of stakeholders to identify key barriers and examined their interrelationships with the DEMATEL. Relationships between barriers were discussed under the respective stakeholders' perspectives. Similarly, Nilashi et al., (2019) revealed the inter-relationships among the factors influencing medical tourism and found the relative importance of these factors utilising the DEMATEL. Besides, Torbacki and Kijewska (2019) adopted the DEMATEL method to identify critical indicators in Logistics 4.0 and Industry 4.0 to meet sustainable urban logistics needs. Even, Quiñones et al., (2020) applied the Delphi method and the fuzzy DEMATEL to carry out university technology transfer barriers and their intertwined relationships. Results indicated that lack of resources has the strongest causal relationship among the 24 UTT barriers. Furthermore, Salehi et al., (2020) employed the DEMATEL technique and Analytic network process (ANP)/method known as DANP to identify the relationship between technology barriers at the supply chain level and prioritise them. The results of DEMATEL showed that the strategic barrier indicator acts as the most influential, and the supply chain management barrier indicator is the most impotent one. Xu et al., (2020) identified critical barriers to the hydrogen refuelling stations (HRS) development through a literature survey and expert consultation. They utilised a K-means clustering algorithm to optimise the threshold value, and thus a modified fuzzy DEMATEL approach was proposed to investigate the prominence of these barriers and the cause-effect relationships among them. The results revealed that six 
barriers were regarded as key barriers to China's HRS development, and corresponding policy measures were formulated to mitigate or eliminate these critical barriers. Song et al., (2020) developed an integrated method based on improved DEMATEL, Interpretive Structural Modelling (ISM) and rough set theory. Their proposed approach integrated the advantages of modified DEMATEL method in determining cause-effect relationships considering the barrier strength impact on the influences, the merits of ISM approach in constructing the hierarchical barrier structure, and the advantages of rough number in flexibly manipulating the vagueness without any extra auxiliary information or pre-assumptions.

Application of the DEMATEL method to problems related to the COVID-19 pandemic has been conducted in the literature also. Dizbay and Öztürkoğlu (2020) highlighted the importance of demand forecasting for the COVID-19 vaccine. They conducted the DEMATEL method to find the cause-and-effect relationships among the factors and provide insights to managers for a better vaccine demand forecast. Their study revealed that immunisation-related beliefs are the most critical factor for vaccine demand forecast. Maqbool and Khan (2020) identified ten barriers to implement public health and social measures to prevent transmission of COVID-19 and used the DEMATEL method to find the casual relationships among these barriers. In another study, Kashyap and Raghuvanshi (2020) identified the critical success factors for developing COVID-19 preventive strategies to control the pandemic using the fuzzy logic-based DEMATEL method. Furthermore, Sorooshian (2020) using the DEMATEL method endeavoured to help decisionmakers based on the cause and effect sources of COVID-19 infection in practice. Numerous authors also highlighted that the DEMATEL method is one of the most accepted methodologies in operational research, dealing with direct and indirect interrelationships and cross infection among cities. One of the main advantages of using the DEMATEL method in this study is that it provides a graph showing causal relations among regions. Altuntas and Gok (2021) investigated the effect of the COVID-19 pandemic on domestic tourism by the DEMATEL method. This method provided correct and consistent solutions to determine the quarantined regions and the causative effects on the rest of Turkey's regions.

\subsection{Factors influencing fear of failure}

Originally, Fear of Failure was described in psychology as the motive to avoid failure as opposed to the motive to achieve success (McClelland et al., 1953). Subsequently, Atkinson and Feather (1966) provided a new definition for this phenomenon: "disposition to avoid failure and/or the capacity for experiencing shame and humiliation as a consequence of failure" and as the "disposition to become anxious about failure under achievement stress". It is worth mentioning that in Rothblum's view, psychologists could examine Fear of failure from the perspective of inhibitions in intellectual pursuits and underachievement (Rothblum, 1990; Mokhtarzadeh et al., 2021). In a more recent model for Fear of Failure (FOF), Conroy et al., (2002), for the first time in the history of research on FOF, classified them into the following categories:

1) fear of experiencing shame and embarrassment;

2) fear of devaluing one's self-estimated;

3) fear of having an uncertain future;

4) fear of important others losing interest;

5) fear of upsetting important others.

According to Chua and Bedford (2016) inductive thematic analysis, twelve lower-order categories were divided into three themes of financial, psychological, and career consequences. Cacciotti et al., (2016) came up with a multi-dimensional model of FoF, examined it in the fields of economics, psychology, and, in a more isolated sense, social-psychological. The economic implication of FoF 
suggested that its perceptions negatively influence entrepreneurship as a career path. In the socialpsychological view, it is a characteristic relevant to one's socio-cultural aspects which focus on how one is rewarded in social contexts. In purely psychological terms, this phenomenon is the type of emotion that results from foreseeing the possible negative outcomes that lead to failure and are psychological and behavioural. This model was divided into seven separate dimensions as follows:

1) fear of loss or the potential for loss of the entrepreneur's livelihood and stored wealth if the venture fails;

2) fear of the (in)ability to perform actions or tasks associated with the pursuit of an opportunity or idea, and/or the development of the venture;

3) fear of the (in)ability to generate or attract the necessary financial capital for the venture;

4) fear regarding the true potential of the opportunity or idea on which the venture is based;

5) fear regarding how others might perceive the entrepreneur should she or he take a misstep or fail;

6) fear of the venture team or organisation's (in)ability to carry out the tasks needed for success;

7) fear of the opportunity costs associated with dedicating time and resources to developing a venture that might fail.

Some scholars have focused on investigating the influence of fear of failure (FoF) on entrepreneurial activities recently. Ng and Jenkins (2018) have investigated different aspects of these effects in four directions: (1) the attractiveness of entrepreneurship as a career choice, (2) an individual's perception of financial risk towards starting a business, (3) how rurality influences FoF and (4) the influence of national cultural practices on the relationship between FoF and starting a business. Martins et al., (2018) have identified the impact of features of personality on the entrepreneurial orientation (EO) of university students. To this end, they divided personality indicators into Self-confidence, Fear of failure, Risk-taking, Innovativeness, and Proactiveness. Dutta and Sobel (2020) measured the effect of FoF on entrepreneurs' desire to become entrepreneurs at different levels of economic freedom. For this purpose, they used independent variables such as Entrepreneurship Rate, FoF, Economic Freedom Index, GDP Per Capita Growth, Domestic Credit, Labor Force Participation Rate, and Urban Population. They confirmed that when levels of economic freedom are higher, the impact of FoF on individuals' choice to become entrepreneurs reduces. Cacciotti et al., (2020) conceptualised entrepreneurial FoF as a negative affective reaction based on cognitive appraisals of the potential for failure in the uncertain context of entrepreneurship. Therefore, they developed and validated an instrument to assess the different dimensions of entrepreneurial FoF based on the ability to fund the venture; the potential of the idea; threat to social esteem; opportunity costs; personal ability; and financial security. Factors that measured FoF, their influence on various case studies, and a statistical sample of the research works that were related to the FoF impacts (some of which were investigated above) are illustrated in Table 1.

\section{Insert Table 1 here}

The literature review introduces a set of enormous factors creating FoF. Table 1 illustrates the important fears and some relevant categories. These factors are obtained by different responders such as experts and related students. Despite many relevant research and studies on barriers and their effects on each other, the effects of fears of failure and their interactions have not been investigated to the best knowledge of the authors. Accordingly, this paper employs the DEMATEL 
method to recognize the fears of failure and their interactions which are likely to be managed through root analysis. On the other hand, this paper has considered the Covid-19 pandemic as a global crisis that is assumed as a fear of failure.

\section{Research methodology}

According to the above, the literature review is performed to extract and achieve the appropriate FoF aspects and criteria hierarchical structure and analysis their relation by DEMATEL method. For this purpose, this paper aims to employ the DEMATEL method to identify the most effective factors and analysing relations between them on entrepreneurship. The research framework has been demonstrated in Figure 8 including the Literature review; Fears of failure extraction; Delphi method to finalize FOF; Factor analysis to categorize FOF; DEMATEL method to identify the most effective factors and analyzing relations between the FOF; eventually, Conclusion and discussion.

\section{Insert Figure 8 here}

In the following sections, we illustrate these methods briefly to provide more information.

\subsection{Delphi method}

The Delphi method is an iterative multistage process designed to combine opinion into group consensus. In the first round of this method, after experts respond, the data are summarised. In the second round, a new questionnaire is designed based solely on the results obtained from the first round. The second questionnaire is returned to each expert and they are asked (in the light of the results of the first round), to reconsider their initial opinion and to return their responses once again to the researcher. Repeat rounds of this process are carried out until a consensus, or a point of diminishing returns, has been reached (McKenna, 1994; Mokhtarzadeh et al., 2020).

\subsection{Exploratory Factor Analysis}

Factor analysis is a collection of methods used to examine how underlying constructs influence the responses on several measured variables. There are exploratory and confirmatory types of factor analysis. In this paper, Exploratory factor analysis (EFA) is utilised to discover the nature of the constructs influencing a set of responses. The primary objective of EFA is to determine the number of common factors influencing a set of measures and the strength of the relationship between each factor and each observed measure. The basic steps to performing an EFA is illustrated in (DeCoster, 1998) encompassing Collect measurements; Obtain the correlation matrix; Select the number of factors for inclusion; Extract an initial set of factors; Rotate factors to a final solution; Interpret factor structure, and Construct factor scores for further analysis.

\subsection{DEMATEL method}

DEMATEL was introduced by Battle Memorial Institute between 1972 and 1976 (Salehi et al., 2020). This method is based on directed graphs (known as digraphs) which separates involved criteria into cause group and effect group. A digraph may typically represent a communication network, or some domination relation between individuals, etc. Suppose a system contains a set of elements $\mathrm{S}=\left\{\mathrm{s}_{1}, \mathrm{~s} 2, \ldots, \mathrm{s}_{\mathrm{n}}\right\}$ and pairwise relations are determined for modelling concerning a mathematical relation $R$. Next, portray the relation $R$ as a direct-relation matrix that is indexed equally on both dimensions by elements from the set $S$. Then, for none relation, the number 0 appears in the cell $(\mathrm{i}, \mathrm{j})$, if the entry is a positive integer, this means $(1)$ the ordered pair $\left(\mathrm{si}, \mathrm{s}_{\mathrm{j}}\right)$ is in the relation matrix $R$, and (2) element $\mathrm{s}_{\mathrm{i}}$ causes element $\mathrm{s}_{\mathrm{j}}$ (Tzeng and Huang, 2011; 
Mokhtarzadeh et al., 2018). Tzeng and Huang (2011) defined the DEMATEL method as a potential that has the following benefits:

1) gather group knowledge for capturing the interactions between subsystems,

2) form a structural model of evaluation for making decisions,

3) visualise the causal relationship of subsystems by offering a causal diagram that promotes understanding of the character of the problem, and communicates opinions within a group.

While a basic conceptual model is not available and access to hard data is limited, using multicriteria decision-making (MCDM) methods are very popular. Generally, MCDM approaches are applicable to address different research objectives encompassing measuring the importance of factors/criterias, ranking alternatives, and analysing the relationship among factors (Amoozad Mahdiraji et al., 2020). Based on the benefits of the DEMATEL method and according to the literature review, the DEMATEL method has been widely used to investigate the causal relationships of key barriers based on the collective opinions of experts. As a result, fear of failure is considered as a kind of barrier; therefore, for the first time in this field of study, the DEMATEL method has been employed to investigate the cause-and-effect relationships of fear of failure factors based on the opinions of international Tourism industry entrepreneurs and experts. This method is utilised in the following steps.

Step 1. Calculate the average initial direct-relation matrix (A) by Eq. (1). Where matrix A (average initial direct-relation matrix $)=[a i j]$

$$
a_{i j}=\frac{1}{H} \sum_{k=1}^{H} X_{i j}^{k}
$$

where,

$\mathrm{H}$ number of experts

$\mathrm{n}$ number of factors

$\mathrm{k}$ number of respondent surveyed

$\boldsymbol{X}_{\boldsymbol{i} \boldsymbol{j}}^{\boldsymbol{k}}$ degree of influence for criterion i to criterion $\mathrm{j}$ concerning the $\mathrm{k}_{\mathrm{th}}$ expert

Step 2. Calculate the normalised direct influence matrix $(\mathbf{N})$. The normalised direct influence matrix $\mathbf{N}$ is computed using Eq. (2) and Eq. (3).

$$
\begin{aligned}
& S=\min \left(\max _{1<i<n} \sum_{j=1}^{n} a_{i j}, \max _{1<j<n} \sum_{i=1}^{n} a_{i j}\right), \mathrm{i}, \mathrm{j}=1,2, \ldots, \mathrm{n} \\
& N \text { (the direct influence matrix) }=\frac{A}{S}
\end{aligned}
$$

Step 3. Calculate the total relation matrix (T-TRM). The total relation matrix implies a totalinfluence matrix, and it is calculated using Eq. (4).

$$
T R M=T=N(I-N)^{-1}
$$

where $(I)$ denotes the identity matrix.

Step 4. Set up a threshold value. The threshold value is obtained to draw the impact-digraph-maps of factors. This value is usually determined by the decision-maker or through discussions with experts, or even the average of the values in the TRM matrix (Li and Tzeng, 2009).

Step 5. Final output. The next step is to find out the sum of each row and each column of $T$. The sum of rows (D) and columns (R) are calculated using Eq.(5) and Eq.(6) as follows:

$$
D=\sum_{j=1}^{n} T_{i j}
$$




$$
R=\sum_{i=1}^{n} T_{i j}
$$

Then, the values of $D+R$ and $D-R$ are measured by $D$ and $R$, where $D+R$ represents the degree of importance of factor $i$ and $D-R$ represent net effects of that factor.

\section{Finding and Results}

The entrepreneurship attitude is extending in developing countries especially in the tourism field which is considered a profitable industry in recent decades. This industry depends on different factors such as historic buildings, traditional customs, ancient places, climate, art, pleasure time, etc. Many ancient places are located in Iran and the vast areas of the country include different climatic zones which are interesting for visitors, allowing the tourists to travel to Iran all over the year. Accordingly, the tourism-related industries and tourism supply chains look very attractive for job seekers and entrepreneurs. Hence, this industry has been developed in the recent decade, and it proceeded to ascend due to social media and developing applications (Sahoo and BG, 2017; Živković et al., 2014). However, this industry is not yet saturated in Iran (Khodadadi, 2016); thus, many potential entrepreneurs may be interested in it. This behaviour was observed until the covid19 crisis occurred and quarantine and lockdown policies were scheduled around the world. This event changed many anticipations, and it might have created another FoF in this industry. To manage the individual interest toward international entrepreneurship, it is required to recognise the personal FoF and find their importance and priorities them; accordingly, identify and control their impacts on each other. All in all, the entrepreneurial behaviour in tourism industry should be strengthened. In this regard, the present paper focuses on FoF in tourism industry to find the importance and impacts of factors on each other. This process is a fundamental contributor to control the impact of fears on each other and reduce their destructive internal relations. For this purpose, the literature is reviewed, and many factors are recognised as $\mathrm{FoF}$ in entrepreneurship field. The process to select the final fears consists of several steps entitled factor extraction in this paper.

\subsection{Factors Extraction}

The modified Delphi technique (Azadi, et al., 2020) was adopted in this step. For this purpose, five tourism experts participated in the Delphi method to specify the factors. This panel consists of 3 entrepreneurship and management consultants, and 2 entrepreneurs who have worked as tourism entrepreneurs for at least two years. In the first round, the experts received the primary list of $46 \mathrm{FoF}$ from the literature review (as denoted in Table 1) and refined them based on their experiences and opinion. The experts completed online forms and then returned the list and the research team revised and changed the list. In total, 30 items were sent for the second round of Delphi. The experts received the revised list and finally reached a consensus on remained fears in this round. The Delphi method produced a set of 21 finalised fears, which were organised as a questionnaire to be distributed among entrepreneurs, tourism entrepreneurs, and entrepreneurship students and consultants as presented in Table 2 .

\section{Insert Table 2 here}

In the next step, the decision-makers were to imply their opinion on FoF for international entrepreneurs in the tourism industry and prioritise them. To facilitate this process, it seems better to categorise these several fears into factors including few items. For this purpose, a questionnaire was developed and items were rated on a Likert scale of $5=$ very important, $4=$ important, $3=$ 
moderately important, 2 = less important, and 1 = unimportant. The Kaiser-Meyer-Olkin (KMO) sampling adequacy measurement was performed to evaluate the applicability of factor analysis for the sampling group. Such an evaluation was conducted before determining the factor structure of the FoF scales. Besides, Bartlett's test of sphericity was employed to identify if the factor analysis of the sampling group was appropriate and more than zero. The KMO coefficient of the fear of failure scales is 0.798 . Moreover, their chi-square value for Bartlett's test of sphericity is significant at 821.066 (Table 3).

\section{Insert Table 3 here}

The findings indicated that the sample size is appropriate for factor analysis.

\section{Insert Table 4 here}

According to factor analysis results in Table 4, 21 fears of failure were divided into 6 aspects entitled as Table 5.

* Fears related to the procedure $\left(\mathrm{C}_{1}, \mathrm{C}_{2}, \mathrm{C}_{3}, \mathrm{C}_{4}, \mathrm{C}_{5}, \mathrm{C}_{6}\right)$

* Fear of future $\left(\mathrm{C}_{7}, \mathrm{C}_{8}, \mathrm{C}_{9}, \mathrm{C}_{10}, \mathrm{C}_{11}\right)$

* Environmental fears $\left(\mathrm{C}_{12}, \mathrm{C}_{13}, \mathrm{C}_{14}, \mathrm{C}_{15}\right)$

$$
\begin{aligned}
& \text { Moral fears }\left(\mathrm{C}_{16}, \mathrm{C}_{17}\right) \\
& \text { * Fear of losing credit }\left(\mathrm{C}_{18}, \mathrm{C}_{19}\right) \\
& \text { Fear of loneliness }\left(\mathrm{C}_{20}, \mathrm{C}_{21}\right)
\end{aligned}
$$

Prioritising a large number of fears and distinguishing their effects on each other is ambiguous and misleading. Factor analysis divided these fears into homogenous groups; this factor grouping facilitates and simplifies the process of scoring and prioritising the fears for decision-makers.

\section{Insert Table 5 here}

To analyse the impact of FoF criteria for international entrepreneurs in the tourism industry, five tourism experts who studied entrepreneurship management research participated in the expert evaluation panel (same experts in Delphi stage). For this purpose, the relations among the 21 criteria and 6 aspects in a hierarchical structure (as in Table 5) and the direct influence matrices were generated for each expert. These direct influences were judged by experts with relative $0-4$ scales according to Table 6. Subsequently, a direct-relation matrix for each expert was obtained. To aggregate experts' opinions, the arithmetic mean was used to generate an average initial directrelation matrix.

\section{Insert Table 6 here}

These matrices were normalised by Eq. (2) and according to Eq. (3), the total relation matrixes were obtained. All total relation matrices are shown in Figure 9.

\section{Insert Figure 9 here}

According to the results of DEMATEL, the threshold value of each factor was decided by the experts. The threshold value of each aspect from aspects 1 to 6 was set $0.45,0.85,0.5,1.8,1.75$ and 1.25 , relatively. The impact digraph-maps of DEMATEL method results were obtained and shown in Figure 10.

\section{Insert Figure 10 here}


As Figure 10 indicates the "Fears related to procedure" are remarkably interrelated and intertwined. Moreover, it shows that "Fears of the future" affect many other groups of fears in front of entrepreneurs. This status is true of the environmental fears which affect other types of fears. These relationships and effects are described in detail in the discussion section.

Finally, the values of $\mathrm{D}$ and $\mathrm{R}$ were resulted based on Eq. (5) and Eq. (6), respectively. In Table 7, D, R, (D+R), and (D-R) values are presented.

\section{Insert Table 7 here}

As shown in Table 7, $(\mathrm{D}+\mathrm{R})$ represents the degree of importance each factor plays in the entire system. In other words, $(\mathrm{D}+\mathrm{R})$ indicates both impacts on the system and by the system on a specific factor. (D-R) represents the degree of a factor's influence on the system. In general, the positive value of $D-R$ represents a causal variable, and the negative value of $D-R$ represents an effect. The results denote that fear of future group $(D+R=9.376)$ has the most strength effect on other groups of fears. "Fear of losing credit" stands on the second step of affecting feature (9.310). These results are more analysed and investigated in the next section.

\section{Discussion}

According to DEMATEL results, "fear of the future" is the most important one (9.37) amongst others that indicates the ambiguity which is out of control is frightening and withholding. Furthermore, based on the study of Conroy et al., (2002), tourism entrepreneurs have a higher competence since their future performance is most important to them (i.e. less competent performers may believe that they have nothing to lose in the future if they fail). Most of the fears are caused by a lack of information (Seanor and Meaton, 2008; Yagnik and Chandra, 2019). This ambiguity is more tangible in the international tourism industry which relies on different concepts such as relationships, and probable crisis, etc. This factor also affects all others excluding environmental and consists of "Fear of uncertain future"; "Monetary loss"; "Bankruptcy"; "Career damage"; and "Crisis" (Tubadji et al., 2019). These fears present the extreme state of a phenomenon including several aspects which are fundamentally necessary for being successful in entrepreneurs' careers. A successful professional career and lifestyle are necessary for an optimistic future in Iran. "Fear of losing credit" (9.130) has been ranked second demonstrating that "Fear of important others losing interest" and "Disappointing others" are mentally important, and humans pay attention to their relations and they care about close colleagues in Iran. The tourism industry requires specialists and managers to carry out operational and marketing steps that are very costly. An entrepreneur is not able to pay these expenditures at first. Therefore, he/she needs a large network of close relations to organise these tasks at a lower cost. Thus, close colleagues are doubly important for entrepreneurs in the tourism industry. This factor includes dependent fears and is influenced by other groups of factors. Although these fears are indirect and are caused by other aspects of failure, they are important fears and should be considered as a major part of the culture of a nation. This coincides with Ng and Jenkins (2018) which emphasised that losing interest dampens the impact of entrepreneurial self-efficacy on entrepreneurial intentions.

The "environmental fears" stand on the third. This factor is based on rules and regulations, policies, risk threats, and bank laws. Rules and regulations are important parts of environmental aspects and affect severely the other factor groups (1.08). The results indicated that the rules and regulations which are out of control produce other types of fears; because they may lead to ambiguity in the future situation and complicate the procedures. The policies and regulations are remarkably leader 
factors in the tourism industry and indicate the road map of active companies. This is consistent with Nawaser et al., (2011) research, which discussed that regulation factors are the obstacles to achieving appropriate entrepreneurship development in Iran. This factor also has financial and personal reputation impacts that create another group of fears. Finally, this factor causes loneliness for those who have faced failure. "Fear related to procedures" includes the fears which depend on the person and are controllable by individual tact. The entrepreneur chooses an idea that is more likely to be implemented, improves their ability to manage the process by training, and finally selects the best business partners carefully. As the tourism industry needs a creative and innovative personality; hence, needless restricting frameworks. Thus, this design should be planned very carefully and based on realistic facilities to satisfy the expectations of an entrepreneurial and innovative tourism enterprise. The balance between life and work is also provided while the entrepreneur is properly increasing his/her personal and professional abilities. This factor is naturally associated with the operational part of entrepreneurship and approximately illustrates an independent feature of fear that is rarely affected by future and environmental fears. It also has a very low (0.03) impact on other fears that coincides with Cacciotti et al., (2020).

Moral (mental) fears concentrate on very private and personal aspects of failure effects. It involves the probable emotional results of failure such as self-esteem and embarrassment caused by failure. Fear of the future causes this fear. Its impact on other fears is not remarkable because it is completely spiritual and may vary from person to person. However, when this fear comes true, it may lead to another group of fears entitled "losing credit". When the entrepreneur loses his/her self-esteem, its result impacts his/her behaviour aspects. This behaviour is an observable event and provides the conditions for others to judge a failed entrepreneur. Some entrepreneurs are afraid of this judgment and its consequences. Moreover, this fear is highly affected by the future, environment, and procedures (-0.793). Self-esteem is essential for all types of entrepreneurship (Wennberg et al., 2013). The "fear of loneliness" is the last one including "debt" and "losing reputation in professional network". This is caused by (1) ambiguity of future which may involve financial costs and (2) uncontrollable environmental rules and policies (-1.260). Most humans are afraid of mistakes that cause debt and undesirable judgments. As the tourism industry is naturally a service, the business invests in services and money will never return if the business fails. Therefore, debt in the service industry cannot be recovered by asset selling and it takes time and energy for debt settlement. the entrepreneur must waste more time additionally to reach the start point again; this situation is completely unfavorable.

In the first group, fears of "monetary loss" and "career damage" are more effective than others and also more realistic. In the same manner, Chua and Bedford (2016) pointed out that failed entrepreneurs whose careers suffered might have difficulty finding a job with reasonable pay because the entrepreneur would be seen as a less favorable employee compared to others with more professional work experience. On the contrary, "bankruptcy" is a dependent fear resulted from two previous fears. Failure in job status and loss of money separately leads to this significant problem. In the second group, when entrepreneurs lose important close colleagues, they are afraid of being recognised as a disappointing/ frustrating person. Although the third group includes fears of laws, some of them are more prominent, such as government policies that affect other laws and regulations. The fourth group illustrates six types of fears related to procedures. Personal ability impacts every other fear significantly, where the most influential fear of this group is work-life balance emanated from ambiguous and worrying circumstances. Fear related to low self-estimate is an embarrassing emotion and weakens a person's spirit in the fifth group of factors. Finally, 
according to the fears of the sixth group, the fear of "debt and financial need" results in entrepreneurs feeling they have lost their reputation reliability (Chua and Bedford, 2016).

\section{Conclusion}

According to the important role of tourism-related industry in nations GDP and the giant movement toward entrepreneurship and startups that is significantly caused by social media and high-speed Internet, the role of human resource and their attendance in this path becomes more critical. Their participation in entrepreneurship is affected by many factors especially "fears of failure". In this regard, this paper discussed the incorporation of DEMATEL for the analysis of fear of failure that influences the international entrepreneurs in the tourism industry in Iran. The DEMATEL method generates the cause-and-effect diagram through the incorporation of expert opinion. Based on the literature review and Delphi method with experts participation, 21 criteria were categorised under six aspects by factor analysis. The DEMATEL as a structural model for decision making gathered group knowledge and captured the interactions in subsystems and visualised these causal relationships using diagrams. The DEMATEL framework was applied to recognise the causal relationship diagrams. According to the categorisation of the primary FoF, the most influencing FoF, and cause and effect grouping have resulted. This study revealed the significant FoF (cause) which affects the international entrepreneurs' behaviour in the tourism industry.

The first two fears were respectively "fears of future" which were caused by the unclear situation; and "fear of losing credit" that was due to the importance of "relationships" in Iranians' culture. In this regard, at first steps, the importance of "market research" was revealed and emphasised to assure entrepreneurs' minds. The international market is completely ambiguous for entrepreneurs; thus, this study is essential for them to reach some information about international markets and entrepreneurship ecosystems. This research captured various dimensions of the future and developed different scenarios that help entrepreneurs make the best decisions based on research achievements considering the limited resources. Along with this research, it seems necessary for entrepreneurs to take part in personal development workshops and actualise their self-esteem. It implies that training is important whether in a professional and technical field or personality and behavioural dimensions. Spiritual power improves and strengthens entrepreneurial practices and activities. It is also necessary for potential entrepreneurs to reach more information that reduces the ambiguity to some extent. To this purpose, consulting in different managerial aspects may omit the dark points of the decision-making process. These guidelines are available in different issues like Feasibility Study, Business Plan development, risk management, etc. to protect the entrepreneurs from environmental risks and threats. These approaches directly decrease the fears of the future and relevant root causes.

On the other hand, loneliness was the least influencing FoF based on the causal relationship diagram. This implies that feeling caused due to being alone has less influence on international entrepreneurship behaviour. The findings will help to understand the most critical FoF, the least significant FoF, and the interactions among them. This understanding will be beneficial to the entrepreneurs to improve their awareness about the FoFs and their effects. The improved understanding and awareness in these aspects will help them in the successful eradication of the critical fears to start a new startup in the tourism industry. The FoF considered in the study is particularly extracted from tourism industry experts in Iran. On the other hand, with the application of the demonstrated method and removal of the FoF, the entrepreneurs can extend the study to the tourism industry in other geographical locations and even to other industries such as medical 
tourism, etc. Furthermore, the proposed method and discussions on the inferred results are adoptable by researchers from other domains of business management.

For further studies, it is suggested to prioritise the FoF through appropriate decision-making methods in an ambiguous situation. Furthermore, it is recommended to rank and prioritise the solutions to reduce the destructive effects of those fears. These findings should be considered significantly influenced by the country's national culture and customs. Therefore, in case the structure and characteristics in other developing countries were similar, thus; the findings are generalisable and extendable to other developing countries or emerging economies. Furthermore, with the demonstrated methodology, new findings are detectable by including suitable FoF to launch a new startup in developed countries. Thus, the conducted study will serve as a roadmap for entrepreneurs to enhance their practices in their startups. However, the current research is single-stage while possible to be performed as multi-stage research using a control group to examine the findings in different situations and enhance the results of the study. Furthermore, this study has been implemented during the Covid-19 pandemic crisis and it may result differently in the post-Covid era.

\section{References}

Alstete, J.W. (2002), "On becoming an entrepreneur: An evolving typology", International Journal of Entrepreneurial Behaviour and Research, Vol. 8 No. 4, pp. 222-234.

Altuntas, F., and Gok, M.S. (2021), "The effect of COVID-19 pandemic on domestic tourism: A DEMATEL method analysis on quarantine decisions", International Journal of Hospitality Management, Vol. 92, pp.102719.

Amoozad Mahdiraji, H., Hafeez, K., Kord, H. and Abbasi Kamardi, A. (2020), "Analysing the voice of customers by a hybrid fuzzy decision-making approach in a developing country's automotive market", Management Decision, Vol. ahead-of-print No. ahead-of-print.

Anderson, R.B. (2002), Aboriginal entrepreneurship and business development. Captus Press.

Atkinson, J. W., and Feather, N. T. (1966), A theory of achievement motivation (Vol. 66), Wiley New York.

Azadi, T., Sadoughi, F. and Khorasani-Zavareh, D., (2020), "Using modified Delphi method to propose and validate the components of a child injury surveillance system for Iran", Chinese Journal of Traumatology, Vol. 23, No. 5, pp. 274-279.

Blank, S., and Dorf, B. (2013), Podręcznik startupu. Budowa wielkiej firmy krok po kroku. Helion.

Bosma, N., Hill, S., Ionescu-Somers, A., Kelley, D., Levie, J., and Tarnawa, A. (2020), "Global Entrepreneurship Monitor 2019/2020 Global Report”, In Global Entrepreneurship Research Association (GERA).

Boudlaie, H., Mahdiraji, H.A., Shamsi, S., Jafari-Sadeghi, V., and Garcia-Pereze, A. (2020), "Designing a human resource scorecard: An empirical stakeholder-based study with a company culture perspective", Journal of Entrepreneurship, Management and Innovation, Vol. 16, No. 4, pp. 113-147.

Business Review, 2019. [Online] Available at https://business-review.eu/business/fear-of-failure-andmentality-the-main-obstacles-for-those-who-want-to-start-a-business-in-romania-197929

Cacciotti, G., Hayton, J.C., Mitchell, J.R., and Allen, D.G. (2020), "Entrepreneurial fear of failure: Scale development and validation”, Journal of Business Venturing, Vol. 35, No. 5, pp.106041.

Cacciotti, G., Hayton, J. C., Mitchell, J.R., and Giazitzoglu, A. (2016), "A reconceptualization of fear of failure in entrepreneurship”, Journal of Business Venturing, Vol. 31, No. 3, pp. 302-325.

Chua, H.S., and Bedford, O. (2016), "A Qualitative Exploration of Fear of Failure and Entrepreneurial Intent in Singapore”, Journal of Career Development, Vol. 43, No. 4, pp. 319-334.

Conroy, D.E., Willow, J.P., and Metzler, J.N. (2002), "Multidimensional Fear of Failure Measurement: The Performance Failure Appraisal Inventory”, Journal of Applied Sport Psychology, Vol. 14, No. 2, pp. 76-90.

Dana, L.P., and Wright, R.W. (2009), "International entrepreneurship: Research priorities for the future”, 
International Journal of Globalisation and Small Business, Vol. 3, No. 1, pp. 90-134.

DeCoster, J. (1998), Overview of Factor Analysis, Retrieved 19 March 2021, http://www.stathelp.com/notes.html

Dizbay, İ.E., and Öztürkoğlu, Ö. (July 2020), "Determining Significant Factors Affecting Vaccine Demand and Factor Relationships Using Fuzzy DEMATEL Method”, International Conference on Intelligent and Fuzzy Systems, pp. 682-689.

Dutta, N., and Sobel, R.S. (2020), "Entrepreneurship, fear of failure, and economic policy”, European Journal of Political Economy, Vol. 66, pp.101954.

Gabus, A., and Fontela, E. (1972), "World problems, an invitation to further thought within the framework of DEMATEL", Battelle Geneva Research Center, Geneva, Switzerland, pp. 1-8.

Hajiagha, S.H.R., Mahdiraji, H.A., Tavana, M., and Hashemi, S.S. (2018), "A novel common set of weights method for multi-period efficiency measurement using mean-variance criteria", Measurement, Vol. 129, pp. 569-581.

Hong, J. (2018), "Rise of the Sharing Economy and the Future of Tourism and Tourism Industry", Journal of Business and Hotel Management, Vol. 7, No. 2, pp. 5-11.

Jafari-Sadeghi, V., Dutta, D.K., Ferraris, A., and Del Giudice, M. (2020), "Internationalisation business processes in an under-supported policy context: evidence from Italian SMEs", Business Process Management Journal, Vol. 26 No. 5, pp. 1055-107.

Jafari-Sadeghi, V. (2020), "The motivational factors of business venturing: Opportunity versus necessity? A gendered perspective on European countries”, Journal of Business Research, Vol. 113, pp. 279289.

Jafari Sadeghi, V., Nkongolo-Bakenda, J.M., Anderson, R.B., and Dana, L.P. (2019), “An institution-based view of international entrepreneurship: A comparison of context-based and universal determinants in developing and economically advanced countries", International Business Review, Vol. 28, No. 6, pp. 101588.

Jafari-Sadeghi, V., Garcia-Perez, A., Candelo, E., and Couturier, J. (2021), "Exploring the impact of digital transformation on value creation through technology entrepreneurship: Role of technology readiness, exploration, and exploitation", Journal of Business Research, Vol. 124, pp. 100-111.

Kashyap, A., and Raghuvanshi, J. (2020), "A preliminary study on exploring the critical success factors for developing COVID-19 preventive strategy with an economy centric approach", Management Research: Journal of the Iberoamerican Academy of Management, Vol. 18 No. 4, pp. 357-377.

Khodadadi, M. (2016), "Challenges and opportunities for tourism development in Iran: Perspectives of Iranian tourism suppliers”, Tourism Management Perspectives, Vol. 19, pp. 90-92.

Kuckertz, A., Brändle, L., Gaudig, A., Hinderer, S., Reyes, C.A.M., Prochotta, A., Steinbrink, K. M., and Berger, E.S.C. (2020), "Startups in times of crisis-A rapid response to the COVID-19 pandemic", Journal of Business Venturing Insights, Vol. 13, pp. 00169.

Li, C.W., and Tzeng, G.H. (2009), "Identification of a threshold value for the DEMATEL method using the maximum mean de-entropy algorithm to find critical services provided by a semiconductor intellectual property mall”, Expert Systems with Applications, Vol. 36, No. 6, pp. 9891-9898.

Mahdiraji, H.A., Kazimieras Zavadskas, E., Kazeminia, A., and Abbasi Kamardi, A. (2019), "Marketing strategies evaluation based on big data analysis: a CLUSTERING-MCDM approach", Economic research-Ekonomska istraživanja, Vol. 32, No. 1, pp. 2882-2892.

Mahto, R.V., and McDowell, W.C. (2018), "Entrepreneurial motivation: a non-entrepreneurs journey to becoming an entrepreneur", International Entrepreneurship and Management Journal, Vol. 13, No. 3, pp. 513-526.

Maqbool, A., and Khan, N.Z. (2020), "Analyzing barriers for implementation of public health and social measures to prevent the transmission of COVID-19 disease using DEMATEL method", Diabetes and Metabolic Syndrome: Clinical Research and Reviews, Vol. 14, No. 5, pp. 887-892.

Martins, I., Monsalve, J.P.P., and Martinez, A.V. (2018), "Self-confidence and fear of failure among university students and their relationship with entrepreneurial orientation: Evidence from Colombia", Academia Revista Latinoamericana de Administracion, Vol. 31 No. 3, pp. 471-485. 
McClelland, D.C., Atkinson, J.W., Clark, R.A., and Lowell, E.L. (1953), “The achievement motive”, New York, 5.

McKenna, H.P. (1994), "The Delphi technique: a worthwhile research approach for nursing? "Journal of Advanced Nursing, Vol. 19, No. 6, pp. 1221-1225.

Mokhtarzadeh, N.G., Mahdiraji, H.A., Beheshti, M., and Zavadskas, E. K. (2018), "A novel hybrid approach for technology selection in the information technology industry", Technologies, Vol. 6, No. 1, pp. 34-49.

Mokhtarzadeh, N. G., Mahdiraji, H. A., Jafari-Sadeghi, V., Soltani, A., and Kamardi, A. A. (2020), "A product-technology portfolio alignment approach for the food industry: a multi-criteria decision making with z-numbers", British Food Journal, Vol. 122 No. 12, pp. 3947-3967.

Mokhtarzadeh, N.G., Mahdiraji, H.A., Jafarpanah, I., Jafari-Sadeghi, V., and Bresciani, S. (2021), "Classification of inter-organizational knowledge mechanisms and their effects on networking capability: a multi-layer decision-making approach", Journal of Knowledge Management.

Nawaser, K., Khaksar, S.M.S., Shaksian, F., and Afshar Jahanshahi, A. (2011), "Motivational and Legal Barriers of Entrepreneurship Development”, International Journal of Business and Management, Vol. 6, No. 11, pp. 112-130.

Ng, L., and Jenkins, A.S. (2018), "Motivated but not starting: how fear of failure impacts entrepreneurial intentions”, Small Enterprise Research, Vol. 25, No. 2, pp. 152-167.

Nilashi, M., Samad, S., Manaf, A.A., Ahmadi, H., Rashid, T.A., Munshi, A., Almukadi, W., Ibrahim, O., and Ahmed, O.H. (2019), "Factors influencing medical tourism adoption in Malaysia: A DEMATELFuzzy TOPSIS approach”, Computers and Industrial Engineering, Vol. 137, pp. 106005.

OECD, 2020. [Online] Available at https://www.oecd.org/coronavirus/policy-responses/tourism-policyresponses-to-the-coronavirus-covid-19-6466aa20/ [Accessed 2021 January 7 ].

Onetti, A., Zucchella, A., Jones, M.V., and McDougall-Covin, P.P. (2012), "Internationalization, innovation, and entrepreneurship: Business models for new technology-based firms", Journal of Management and Governance, Vol. 16, No. 3, pp. 337-368.

Quiñones, R.S., Caladcad, J.A.A., Himang, C.M., Quiñones, H.G., Castro, C.J., Caballes, S.A.A., Abellana, D.P.M., Jabilles, E.M.Y., and Ocampo, L.A. (2020), "Using Delphi and fuzzy DEMATEL for analyzing the intertwined relationships of the barriers of university technology transfer: Evidence from a developing economy", International Journal of Innovation Studies, Vol.4, No. 3, pp. 85-104.

Rezaei, M., Jafari-Sadeghi, V., Cao, D., and Mahdiraji, H.A. (2021), "Key indicators of ethical challenges in digital healthcare: A combined Delphi exploration and confirmative factor analysis approach with evidence from Khorasan province in Iran", Technological Forecasting and Social Change, Vol. 167, pp. 120724.

Rezaeisabzevar, Y., Bazargan, A., and Zohourian, B. (2020), "Landfill site selection using multi criteria decision making: Influential factors for comparing locations", Journal of Environmental Sciences, Vol. 93, pp. 170-184.

Rothblum, E.D. (1990), Fear of failure. In Handbook of social and evaluation anxiety (pp. 497-537), Springer.

Sadeghi, V.J., and Biancone, P. Pietro. (2017), "Exploring the drivers of gender entrepreneurship: Focus on the motivational perspectives in USA, Italy, and France”, In Gender and Family Entrepreneurship (pp. 124-141), Routledge.

Sadeghi, V.J., Biancone, P. Pietro, Anderson, R.B., and Nkongolo-Bakenda, J.M. (2019), "International entrepreneurship by particular people "on their terms": A study on the universal characteristics of entrepreneurs in evolving economies”, International Journal of Entrepreneurship and Small Business, Vol. 37, No. 2, pp. 288-308.

Sahoo, S.S., and BG, M. (2017), "Role of social media in promoting tourism business-A study on tourism promotion in Odisha”, International Conference People Connect: Networking for Sustainable Development, (pp. 272-295).

Salehi, R., Asaadi, M.A., Rahimi, M.H., and Mehrabi, A. (2020), "The information technology barriers in the supply chain of sugarcane in Khuzestan province, Iran: A combined ANP-DEMATEL approach”, 
Information Processing in Agriculture.

Seanor, P., and Meaton, J. (2008), "Learning from failure, ambiguity and trust in social enterprise", Social Enterprise Journal, Vol. 4, No. 1, pp. 24-40.

Shen, Y.-C. (2017), "Identifying the key barriers and their interrelationships impeding the university technology transfer in Taiwan: a multi-stakeholder perspective”, Quality and Quantity, Vol. 51, No. 6, pp. 2865-2884.

Shieh, J.I., Wu, H.H., and Huang, K.K. (2010), “A DEMATEL method in identifying key success factors of hospital service quality”, Knowledge-Based Systems, Vol. 23, No. 3, pp. 277-282.

Song, W., Zhu, Y., and Zhao, Q. (2020), "Analyzing barriers for adopting sustainable online consumption: A rough hierarchical DEMATEL method”, Computers and Industrial Engineering, Vol. 140, pp. 106279.

Sorooshian, S. (2020), "Quarantine Decision due to Coronavirus Pandemic ”, Electronic Journal of General Medicine, Vol. 17, No. 4, pp. 1-11.

Startupgenome, 2020. [Online] Available at https://startupgenome.com/article/state-of-the-global-startupeconomy

Sukumar, A., Xu, Z., and Chen, G. (2019), "The influences of social media on Chinese start-up stage entrepreneurship", Proceedings of the European Conference on Innovation and Entrepreneurship, ECIE.

Sukumar, A., Jafari-Sadeghi, V., Garcia-Perez, A. and Dutta, D.K. (2020), "The potential link between corporate innovations and corporate competitiveness: evidence from IT firms in the UK", Journal of Knowledge Management, Vol. 24 No. 5, pp. 965-983.

Szarek, J., and Piecuch, J. (2018), "The importance of startups for construction of innovative economies", Przedsiębiorczość Międzynmahdirajiarodowa, 4(2 International Growth and Entrepreneurship), pp. 69-78.

Tehran Times. (2021), Virus causes $\$ 5.2$ billion damage to Iran's tourism, minister says. https://www.tehrantimes.com/news/458488/Virus-causes-5-2-billion-damage-to-Iran-s-tourismminister.

Torbacki, W., and Kijewska, K. (2019), "Identifying Key Performance Indicators to be used in Logistics 4.0 and Industry 4.0 for the needs of sustainable municipal logistics by means of the DEMATEL method", Transportation Research Procedia, Vol. 39, pp. 534-543.

Tubadji, A., Dietrich, H., Angelis, V., Haas, A., and Schels, B. (2019), "Fear-of-failure and cultural persistence in youth entrepreneurship", Journal of Small Business and Entrepreneurship, pp. 1-26.

Tzeng, G.H., and Huang, J.J. (2011), "Multiple attribute decision making: Methods and applications", In Multiple Attribute Decision Making: Methods and Applications.

Wennberg, K., Pathak, S., and Autio, E. (2013), "How culture moulds the effects of self-efficacy and fear of failure on entrepreneurship", Entrepreneurship and Regional Development, Vol. 25, No. 9-10, pp. $756-780$.

Wu, W.W., and Lee, Y.T. (2007), 'Developing global managers' competencies using the fuzzy DEMATEL method”, Expert Systems with Applications, Vol. 32, No. 2, pp. 499-507.

$\mathrm{Xu}, \mathrm{C}$. , Wu, Y., and Dai, S. (2020), "What are the critical barriers to the development of hydrogen refueling stations in China? A modified fuzzy DEMATEL approach”, Energy Policy, Vol. 142, pp. 111495.

Yagnik, A., and Chandra, Y. (2019), "Using creativity to defeat fear and manage ambiguity for enhancing entrepreneurial decisions", In The Anatomy of Entrepreneurial Decisions (pp. 9-28), Springer.

Živković, R., Gajić, J., and Brdar, I. (2014), “The impact of social media on tourism”, Singidunum Journal of Applied Sciences, pp. 758-761. 


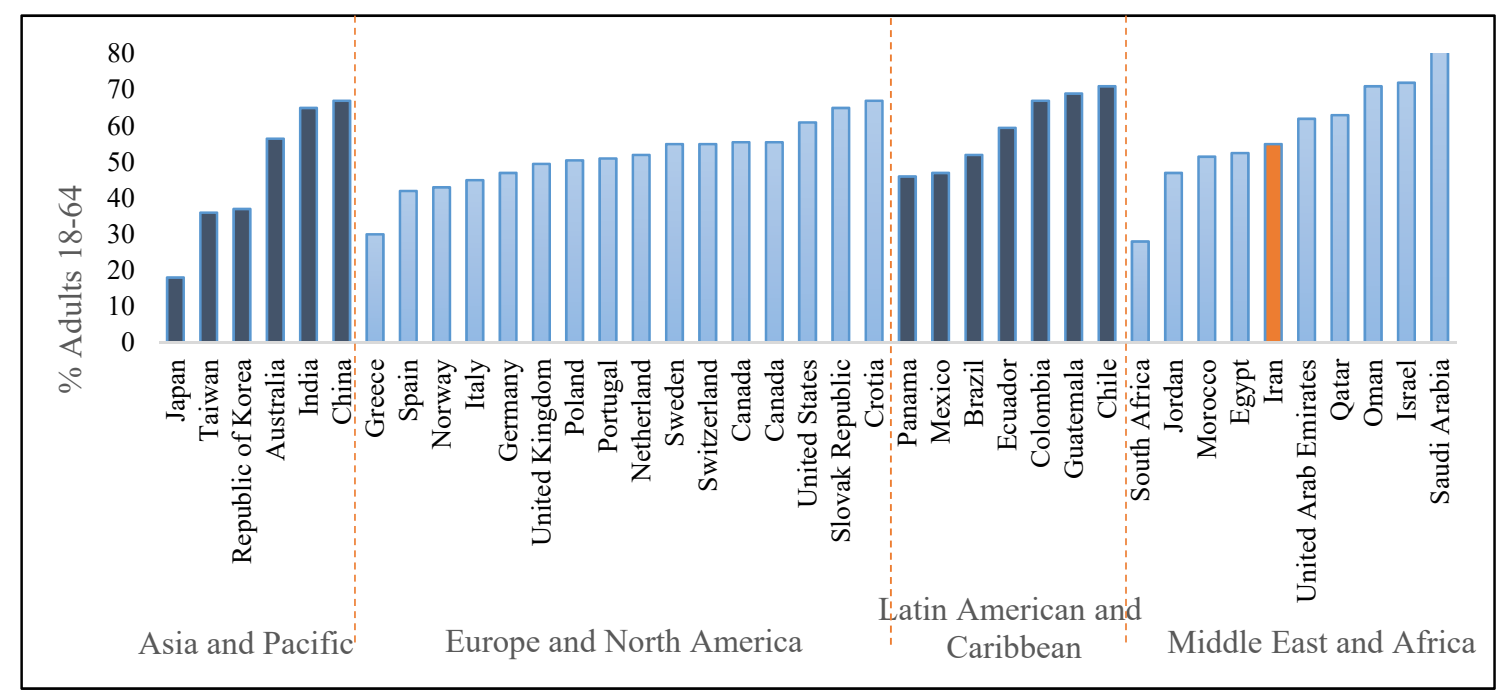

Figure 1. Knowing someone who has started a business in the past two years ( $\%$ adults) 


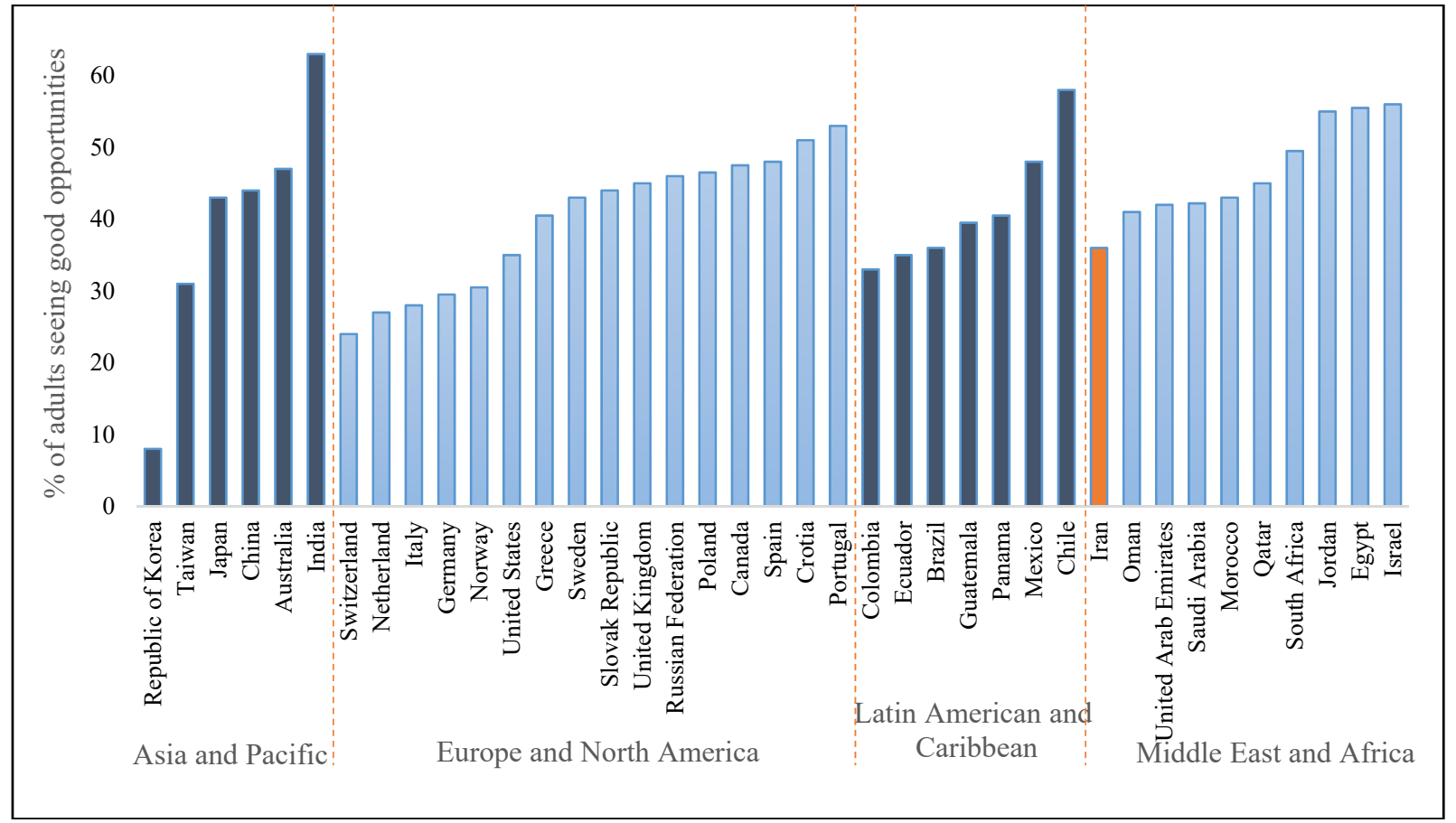

Figure 2. There are good opportunities; however, would not start a business for fear of failure (\% adults) 


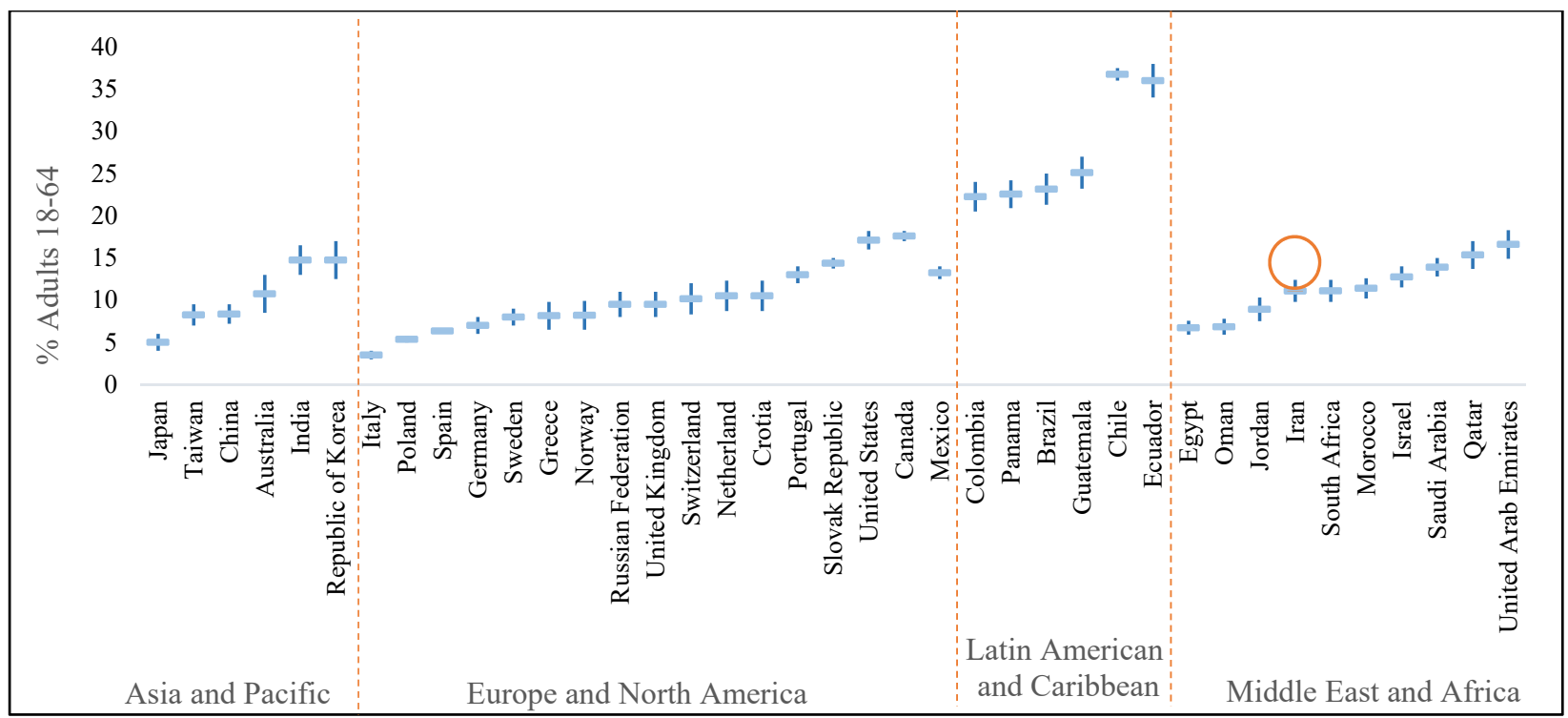

Figure 3. Total early-stage Entrepreneurial Activity (TEA) rate (\% adults) in 50 economies in four regions 


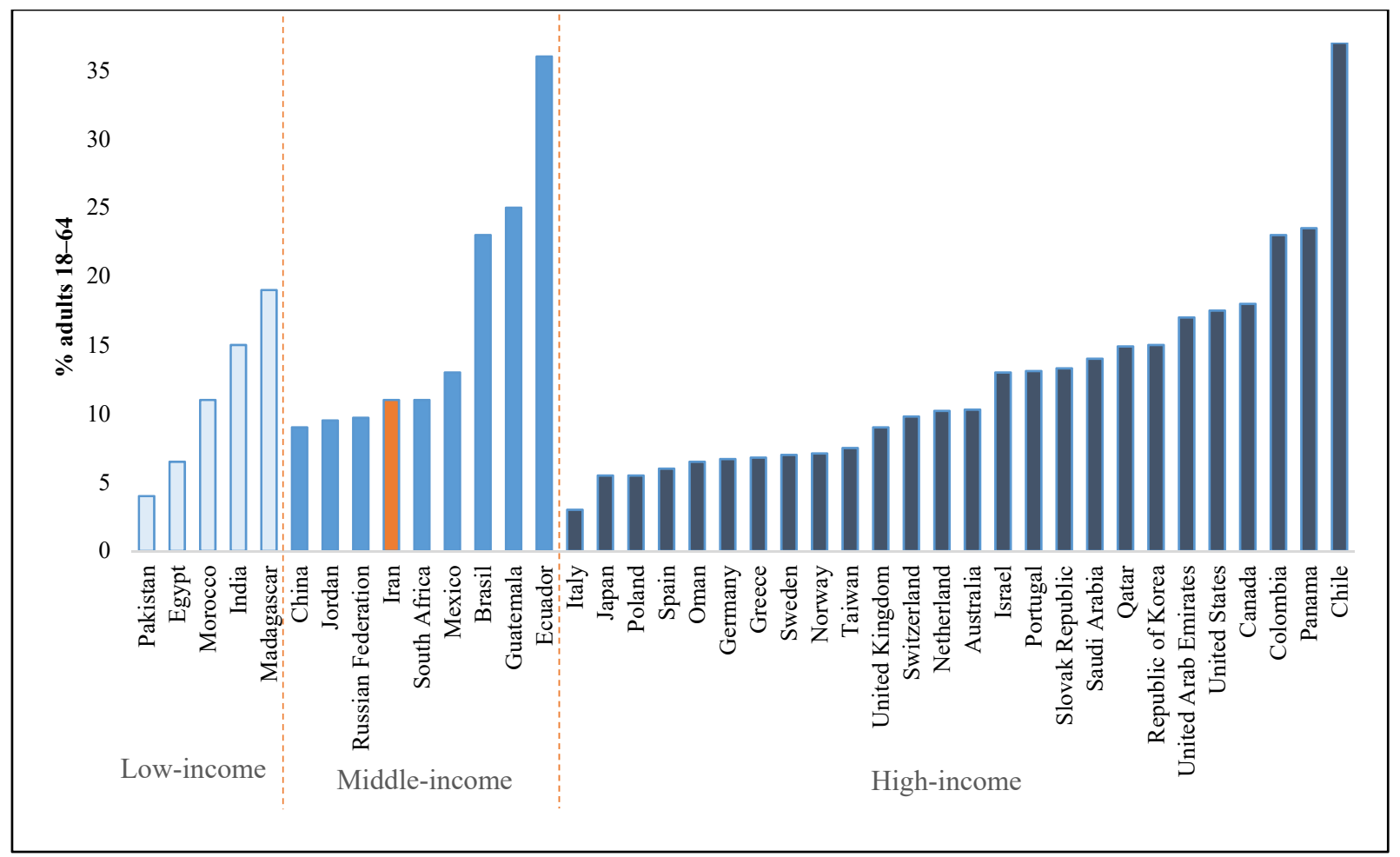

Figure 4. Total early-stage Entrepreneurial Activity (\% adults 18-64), grouped by income level 


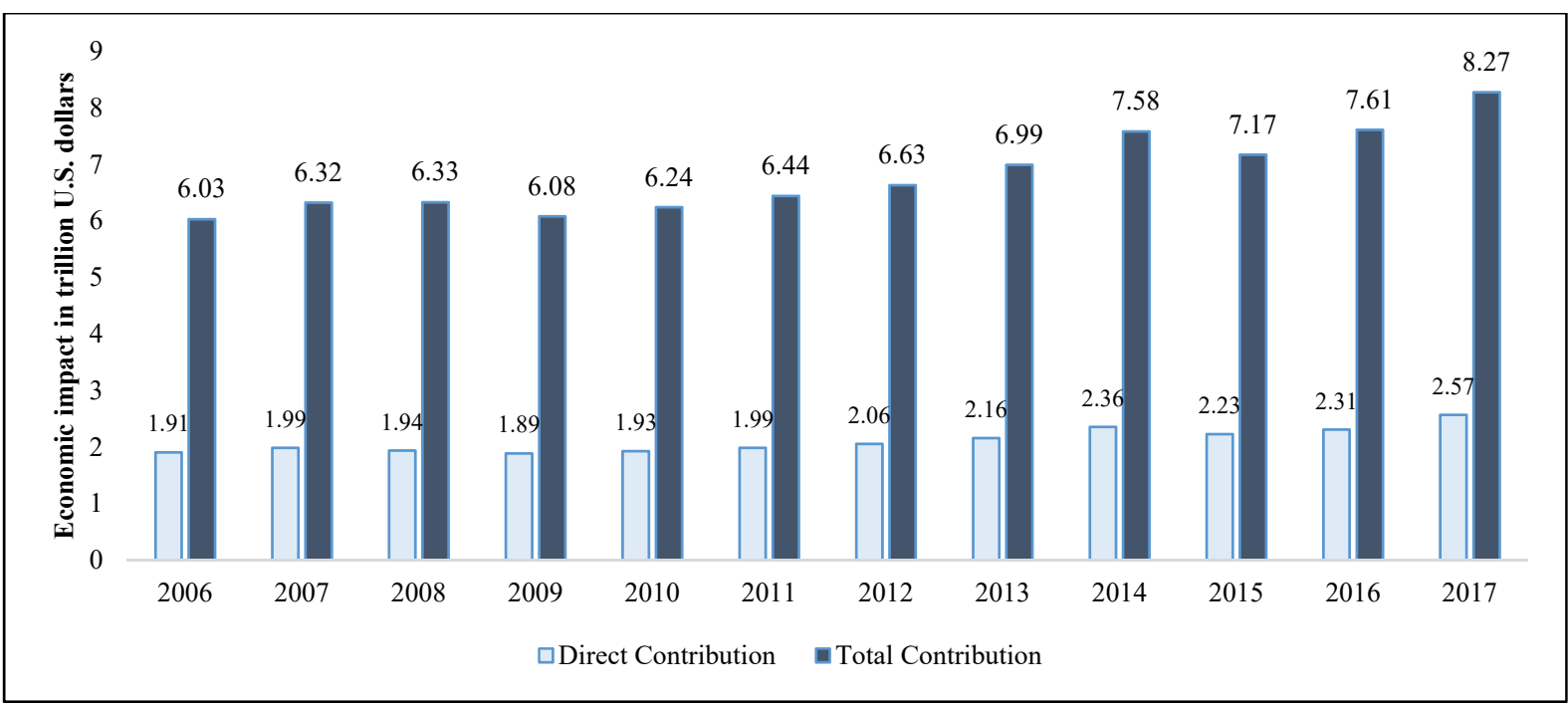

Figure 5. The total and direct contribution of tourism and tourism industry to the global economy 2006-2017 (Hong, 2018) 


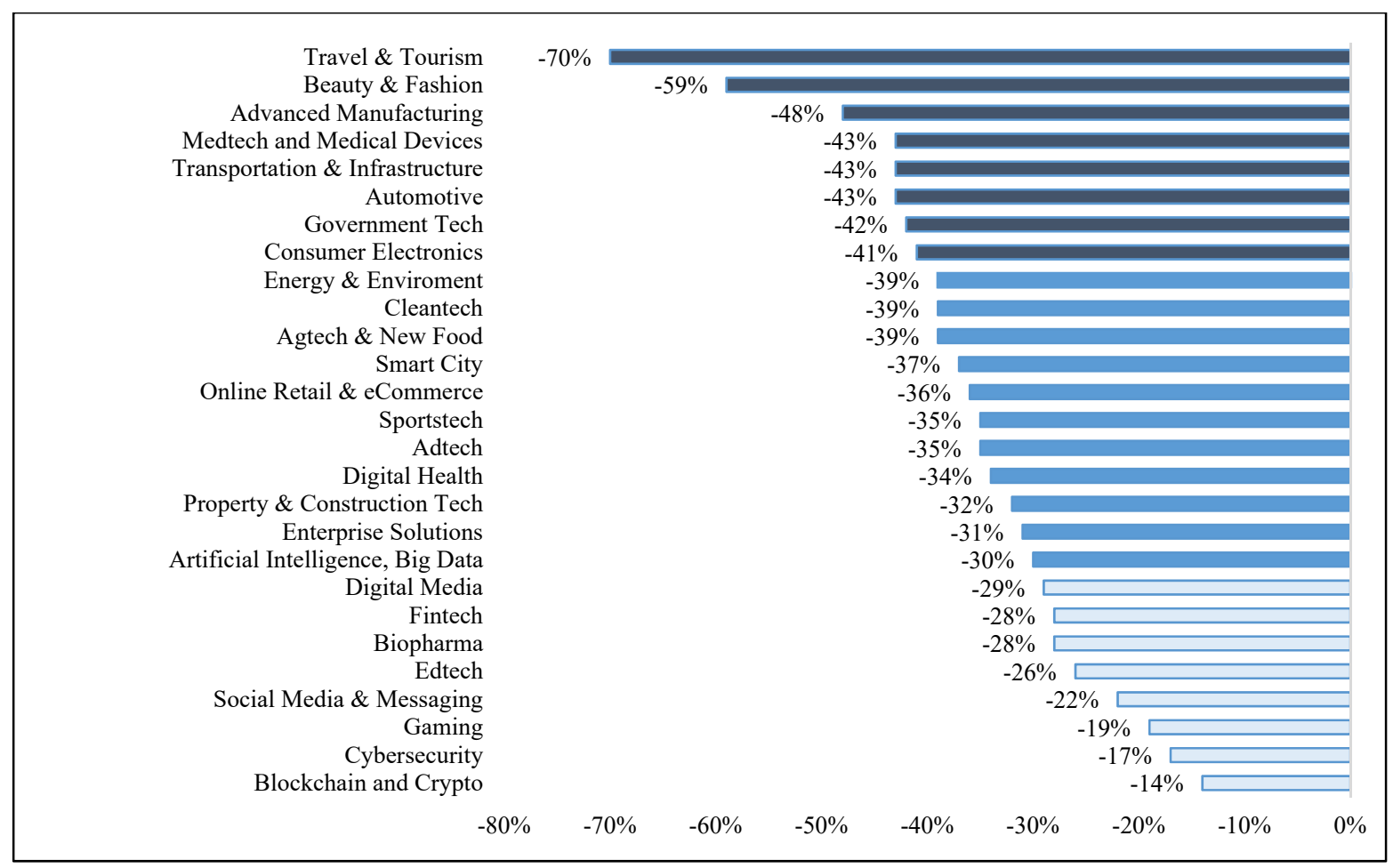

Figure 6. Revenue changes since the beginning of the pandemic by industries Source: Startup Genome, 2020 


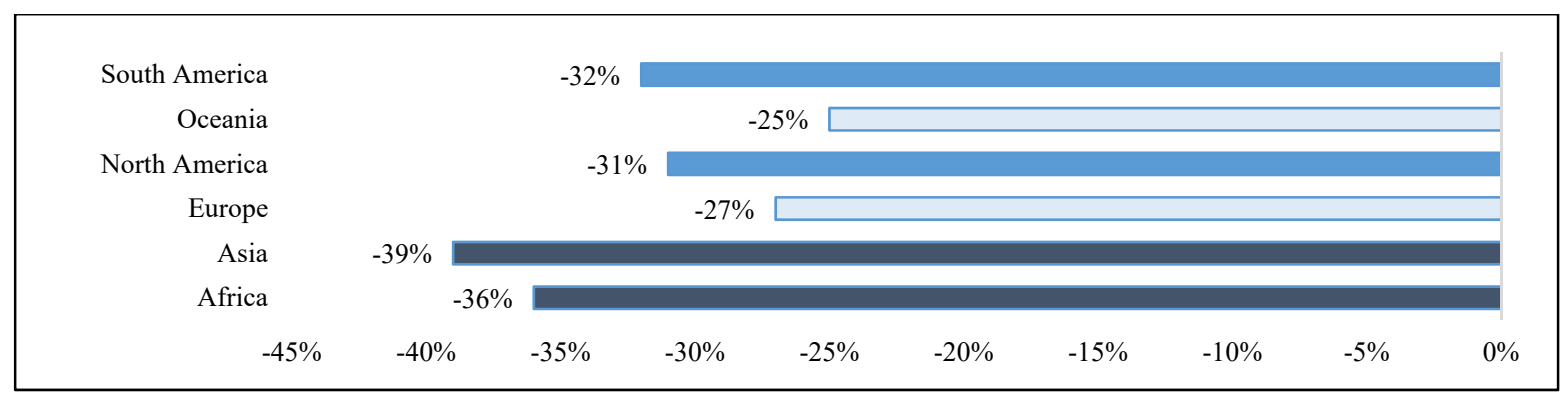

Figure 7. Revenue changes since the beginning of the pandemic by continent Source: Startup Genome, 2020 


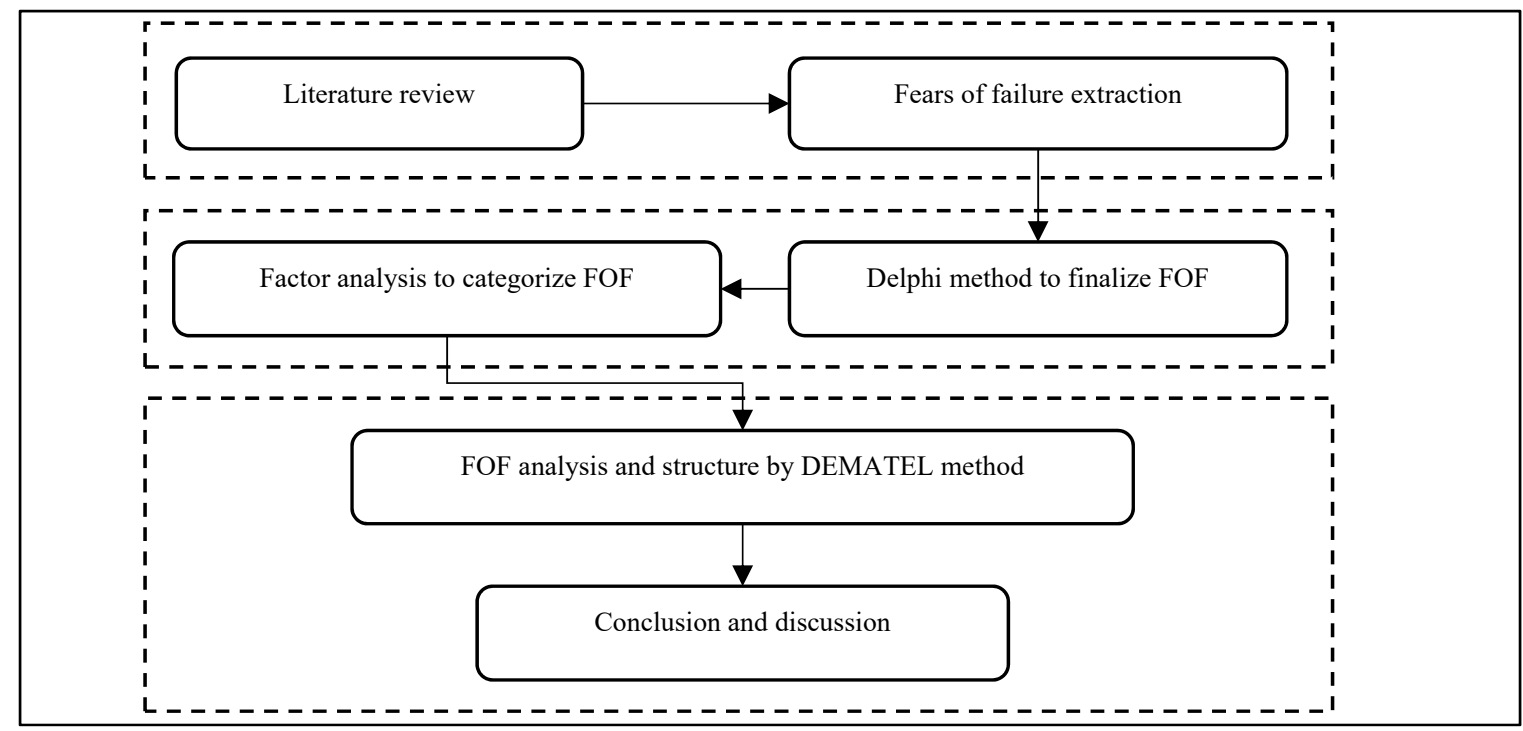

Figure 8. Methodological steps in this research 


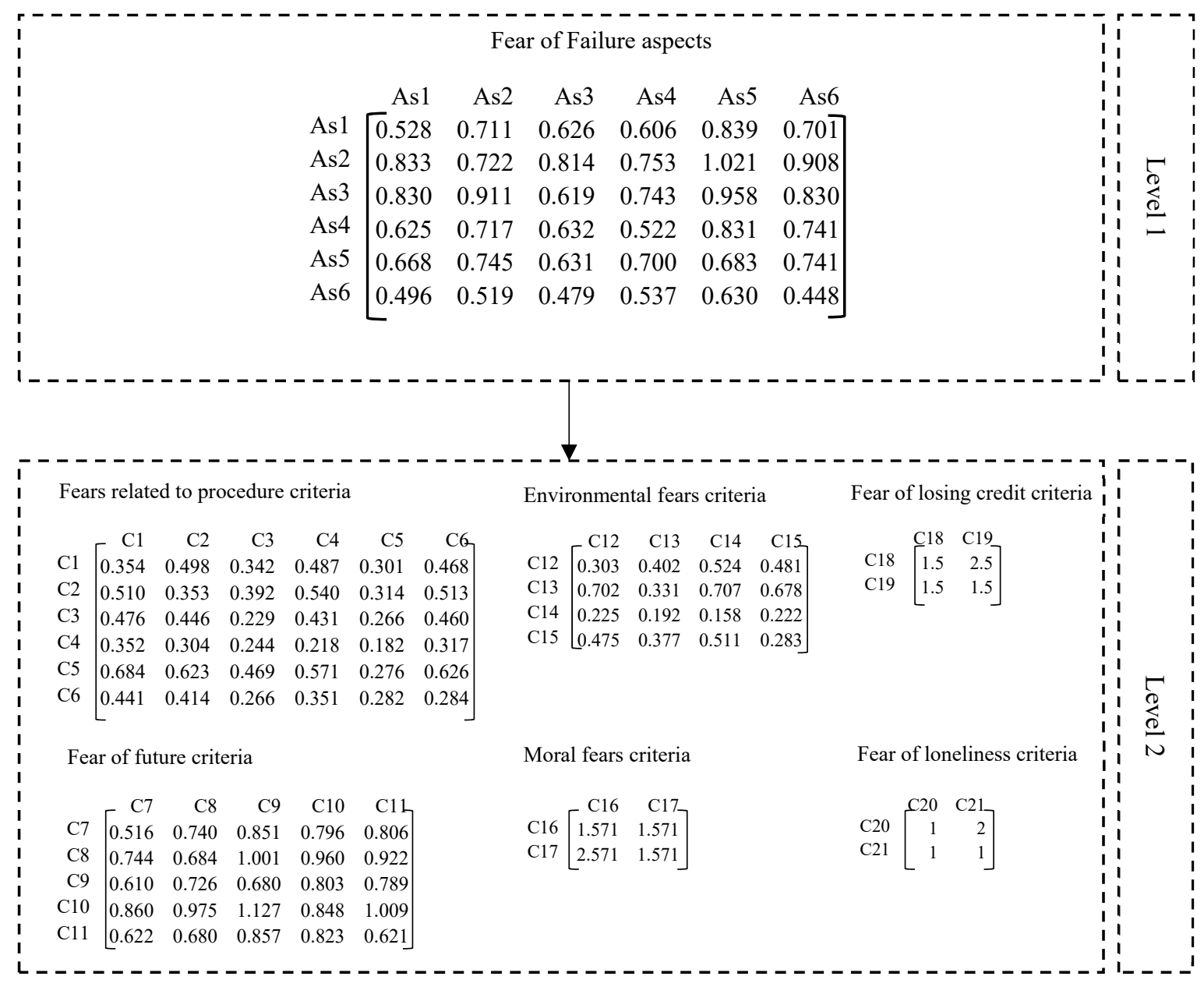

Figure 9. Total relation matrices of fear of failure 


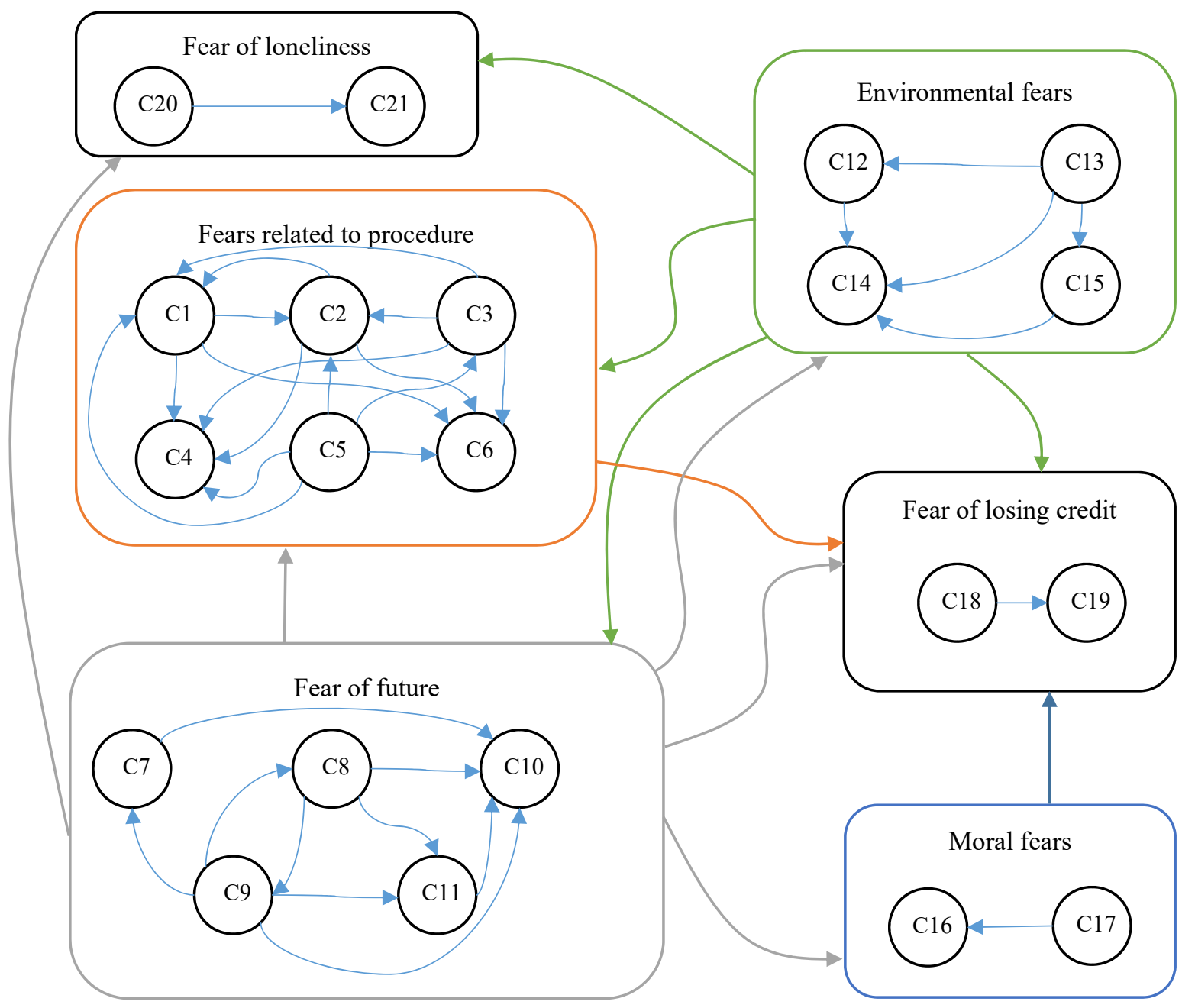

Figure 10. The impact-digraph-maps of six factors derived by DEMATEL method 
Table 1. Factors that measured FoF, its influence on various case studies and statistical sample

\begin{tabular}{|c|c|c|c|}
\hline Author (Year) & Factors & Case study & Statistical sample \\
\hline $\begin{array}{l}\text { Cacciotti, Hayton, } \\
\text { Mitchell, and Allen } \\
(2020)\end{array}$ & $\begin{array}{l}\text { Financial concerns } \\
\text { Personal ability } \\
\text { Opportunity costs } \\
\text { The threat to social esteem } \\
\text { Potential of the idea } \\
\text { Venture's capacity to execute }\end{array}$ & $\begin{array}{l}\text { conceptualization } \\
\text { of entrepreneurial }\end{array}$ & $\begin{array}{l}\text { potential and active } \\
\text { entrepreneurs }\end{array}$ \\
\hline $\begin{array}{l}\text { Dutta and Sobel } \\
(2020)\end{array}$ & $\begin{array}{l}\text { Entrepreneurship Rate } \\
\text { Fear of Failure } \\
\text { Economic Freedom Index } \\
\text { GDP Per Capita Growth } \\
\text { Domestic Credit } \\
\text { Labor Force Participation Rate } \\
\text { Urban Population }\end{array}$ & Entrepreneurship & $\begin{array}{l}\text { GEM database and Fraser } \\
\text { Institute's Economic } \\
\text { Freedom of the World } \\
(\text { EFW) index }\end{array}$ \\
\hline Bosma et al (2020) & $\begin{array}{l}\text { Entrepreneurial finance } \\
\text { Government policies } \\
\text { Cultural and social norms } \\
\text { Internal market burdens or entry } \\
\text { regulation } \\
\text { Internal market dynamics } \\
\text { Entrepreneurial education }\end{array}$ & $\begin{array}{l}\text { Entrepreneurial } \\
\text { framework } \\
\text { conditions }\end{array}$ & Experts \\
\hline $\begin{array}{l}\text { Ng and Jenkins } \\
(2018)\end{array}$ & $\begin{array}{l}\text { Entrepreneurial intention } \\
\text { Entrepreneurial self-efficacy } \\
\text { Fear of important others losing } \\
\text { interest } \\
\text { Fear of devaluing one's self-estimated } \\
\text { Fear of shame and embarrassment } \\
\text { Fear of uncertain future } \\
\text { Fear of upsetting important others }\end{array}$ & $\begin{array}{l}\text { Entrepreneurial } \\
\text { intentions }\end{array}$ & $\begin{array}{l}\text { Third-Year business } \\
\text { management students }\end{array}$ \\
\hline $\begin{array}{l}\text { Martins, Monsalve, } \\
\text { and Martinez } \\
(2018)\end{array}$ & $\begin{array}{l}\text { Self-confidence } \\
\text { Fear of failure } \\
\text { Risk-taking } \\
\text { Innovativeness } \\
\text { Proactiveness }\end{array}$ & $\begin{array}{l}\text { Entrepreneurial } \\
\text { orientation }\end{array}$ & university students \\
\hline $\begin{array}{l}\text { Chua and Bedford } \\
\text { (2016) }\end{array}$ & $\begin{array}{l}\text { Financial Consequences } \\
\text { Psychological Consequences } \\
\text { Career Consequences }\end{array}$ & $\begin{array}{l}\text { Entrepreneurial } \\
\text { Intent }\end{array}$ & university students \\
\hline $\begin{array}{l}\text { Cacciotti, Hayton, } \\
\text { Mitchell, and } \\
\text { (Giazitzoglu, 2016) }\end{array}$ & $\begin{array}{l}\text { Financial security } \\
\text { Personal ability } \\
\text { Ability to finance the venture } \\
\text { Potential of the idea } \\
\text { Social esteem } \\
\text { Venture's ability to execute } \\
\text { Opportunity costs }\end{array}$ & $\begin{array}{l}\text { Entrepreneurial } \\
\text { setting }\end{array}$ & $\begin{array}{l}\text { entrepreneurs and potential } \\
\text { entrepreneurs in the United } \\
\text { Kingdom and Canada }\end{array}$ \\
\hline $\begin{array}{l}\text { Nawaser, Khaksar, } \\
\text { Shaksian, and } \\
\text { Afshar Jahanshahi } \\
\text { (2011) }\end{array}$ & $\begin{array}{l}\text { financial risk } \\
\text { Financial obstacles } \\
\text { financial resources } \\
\text { Corruption } \\
\text { Lack of skills }\end{array}$ & $\begin{array}{l}\text { Development of } \\
\text { entrepreneurship }\end{array}$ & $\begin{array}{l}\text { researchers who had } \\
\text { participated in National } \\
\text { Conference on } \\
\text { Entrepreneurship } \\
\text { Management }\end{array}$ \\
\hline
\end{tabular}




\begin{tabular}{|c|c|c|c|}
\hline Author (Year) & Factors & Case study & Statistical sample \\
\hline & $\begin{array}{l}\text { Social dangers/expenses } \\
\text { Market demand } \\
\text { Gender } \\
\text { Fear of defeat } \\
\text { Competition } \\
\text { Much work } \\
\text { Bank regulations and laws factor } \\
\text { Trade Law } \\
\text { Governmental monopolies } \\
\text { Tax Regulations } \\
\text { Rules and regulations }\end{array}$ & & $\begin{array}{l}\text { and Regional Development } \\
\text { (Ilam University, 2009) }\end{array}$ \\
\hline $\begin{array}{l}\text { Conroy, Willow, } \\
\text { and Metzler (2002) }\end{array}$ & $\begin{array}{l}\text { Fear of experiencing shame and } \\
\text { embarrassment } \\
\text { Fear of devaluing one's self-estimated } \\
\text { Fear of having an uncertain future } \\
\text { Fear of important others losing } \\
\text { interest } \\
\text { Fear of upsetting important others }\end{array}$ & $\begin{array}{l}\text { The Performance } \\
\text { Failure Appraisal } \\
\text { Inventory (PFAI) }\end{array}$ & College students \\
\hline Rothblum (1990) & $\begin{array}{l}\text { self-esteem } \\
\text { Goal-Setting } \\
\text { Risk-Taking }\end{array}$ & $\begin{array}{l}\text { Psychodynamic and } \\
\text { Need Achievement }\end{array}$ & Experts \\
\hline
\end{tabular}


Table 2. Extract of Delphi questionnaire used in round 1 and round 2

\begin{tabular}{ll}
\hline \multicolumn{1}{c}{ Delphi round 1 } & \multicolumn{1}{c}{ Delphi round 2 } \\
\hline Fear of experiencing shame and embarrassment & Fear of experiencing shame and embarrassment \\
Fear of devaluing one's self-estimated & Fear of devaluing one's self-estimated \\
Fear of uncertain future & Fear of uncertain future \\
Fear of important others losing interest & Fear of important others losing interest \\
Disappointing others & Disappointing others \\
Monetary loss & Monetary loss \\
Bankruptcy & Bankruptcy \\
Loss of support/confidence/trust & Career damage \\
Career damage & Lack of ability to pursue the opportunity \\
Lack of ability to pursue the opportunity & Lack of ability to execute entrepreneurial tasks \\
Lack of ability to execute entrepreneurial tasks & The idea too difficult to implement \\
The idea too difficult to implement & Venture's capacity to execute. \\
Loss of status/face/reputation in the eyes of others & Personal ability \\
Venture's capacity to execute. & Crisis \\
financial risk & Rules and regulations \\
Personal ability & Government policies \\
The threat to social esteem & Goal-Setting and Risk-Taking Behavior \\
Crisis & Bank regulations and laws factor \\
Governmental monopolies & Loss of work-life balance \\
Tax Regulations & Debt \\
Rules and regulations & Losing reputation in the professional network \\
Government policies & \\
Cultural and social norms & \\
Internal market burdens or entry regulation & \\
Goal-Setting and Risk-Taking Behavior & \\
Bank regulations and laws factor & \\
Loss of work-life balance & \\
Cultural and social norms & \\
Debt & \\
Losing reputation in the professional network & \\
\hline
\end{tabular}


Table 3. KMO and Bartlett's Test

\begin{tabular}{ll}
\hline & Scale \\
\hline Kaiser-Meyer-Olkin Measure of Sampling Adequacy. & 0.798 \\
Bartlett's Test of Sphericity & 821.066 \\
Df & 210 \\
Sig. & $<0.001$ \\
\hline
\end{tabular}


Table 4. Rotated Factor Matrix ${ }^{\mathrm{a}}$

\begin{tabular}{|c|c|c|c|c|c|c|}
\hline \multirow[b]{2}{*}{ Criteria } & \multicolumn{6}{|c|}{ Fear Factor } \\
\hline & procedure & future & Environmental & Moral & $\begin{array}{l}\text { losing } \\
\text { credit }\end{array}$ & loneliness \\
\hline $\begin{array}{l}\text { Fear of experiencing shame and } \\
\text { embarrassment }\end{array}$ & 0.238 & 0.106 & -0.093 & 0.745 & 0.167 & -0.017 \\
\hline $\begin{array}{l}\text { Fear of devaluing one's self- } \\
\text { estimate }\end{array}$ & 0.277 & 0.212 & -0.064 & 0.669 & 0.217 & 0.120 \\
\hline Fear of uncertain future & 0.116 & 0.567 & 0.032 & -0.039 & 0.081 & -0.007 \\
\hline $\begin{array}{l}\text { Fear of important others losing } \\
\text { interest }\end{array}$ & -0.035 & -0.011 & 0.009 & 0.128 & 0.621 & 0.122 \\
\hline Disappointing others & 0.310 & 0.291 & 0.090 & 0.204 & 0.575 & -0.046 \\
\hline Monetary loss & 0.033 & 0.649 & 0.137 & 0.228 & 0.056 & 0.075 \\
\hline Bankruptcy & 0.396 & 0.503 & 0.118 & 0.155 & -0.062 & 0.061 \\
\hline Career damage & 0.087 & 0.872 & 0.128 & 0.023 & -0.049 & 0.262 \\
\hline $\begin{array}{l}\text { Lack of ability to pursue the } \\
\text { opportunity }\end{array}$ & 0.378 & 0.210 & 0.153 & 0.289 & -0.061 & 0.099 \\
\hline $\begin{array}{l}\text { Lack of ability to execute } \\
\text { entrepreneurial tasks }\end{array}$ & 0.782 & 0.085 & -0.024 & 0.181 & -0.028 & 0.072 \\
\hline Idea too difficult to implement & 0.645 & 0.208 & 0.015 & 0.088 & 0.138 & 0.147 \\
\hline Venture's capacity to execute & 0.464 & 0.217 & 0.010 & 0.008 & 0.099 & 0.262 \\
\hline Personal ability & 0.693 & 0.112 & 0.043 & 0.332 & 0.199 & -0.010 \\
\hline Crisis & 0.309 & 0.613 & -0.018 & 0.233 & 0.137 & 0.016 \\
\hline Rules and regulations & 0.035 & 0.063 & 0.899 & 0.075 & 0.093 & 0.035 \\
\hline Government policies & -0.123 & 0.166 & 0.612 & -0.076 & -0.219 & 0.032 \\
\hline $\begin{array}{l}\text { Goal-Setting and Risk-Taking } \\
\text { Behavior }\end{array}$ & 0.374 & 0.294 & 0.416 & 0.041 & 0.164 & 0.096 \\
\hline Bank regulations and laws factor & 0.211 & -0.003 & 0.690 & -0.126 & 0.160 & 0.238 \\
\hline Loss of work-life balance & 0.414 & 0.012 & 0.169 & 0.147 & -0.074 & 0.321 \\
\hline Debt & 0.204 & 0.216 & 0.216 & -0.047 & 0.059 & 0.683 \\
\hline $\begin{array}{l}\text { Losing reputation in the } \\
\text { professional network }\end{array}$ & 0.208 & 0.054 & 0.046 & 0.353 & 0.308 & 0.493 \\
\hline
\end{tabular}


Table 5. Fear of failures for international entrepreneurs in the tourism industry

\begin{tabular}{|c|c|c|c|c|c|}
\hline Aspects & Code & Criteria & Aspects & Code & Criteria \\
\hline \multirow[t]{6}{*}{$\begin{array}{l}\text { Fears related to the } \\
\text { procedure }\end{array}$} & $\mathrm{C} 1$ & $\begin{array}{l}\text { Lack of ability to pursue the } \\
\text { opportunity }\end{array}$ & $\begin{array}{l}\text { Environmental } \\
\text { fears }\end{array}$ & $\mathrm{C} 12$ & Rules and regulations \\
\hline & $\mathrm{C} 2$ & $\begin{array}{l}\text { Lack of ability to execute } \\
\text { entrepreneurial tasks }\end{array}$ & & $\mathrm{C} 13$ & Government policies \\
\hline & $\mathrm{C} 3$ & $\begin{array}{l}\text { The idea too difficult to } \\
\text { implement }\end{array}$ & & $\mathrm{C} 14$ & $\begin{array}{l}\text { Goal-Setting and Risk-Taking } \\
\text { Behavior }\end{array}$ \\
\hline & $\mathrm{C} 4$ & Venture's capacity to execute. & & $\mathrm{C} 15$ & $\begin{array}{l}\text { Bank regulations and laws } \\
\text { factor }\end{array}$ \\
\hline & $\mathrm{C} 5$ & Personal ability & Moral fears & $\mathrm{C} 16$ & $\begin{array}{l}\text { Fear of experiencing shame and } \\
\text { embarrassment }\end{array}$ \\
\hline & C6 & Loss of work-life balance & & $\mathrm{C} 17$ & $\begin{array}{l}\text { Fear of devaluing one's self- } \\
\text { estimated }\end{array}$ \\
\hline \multirow[t]{5}{*}{ Fear of future } & $\mathrm{C} 7$ & Fear of uncertain future & $\begin{array}{l}\text { Fear of losing } \\
\text { credit }\end{array}$ & $\mathrm{C} 18$ & $\begin{array}{l}\text { Fear of important others losing } \\
\text { interest }\end{array}$ \\
\hline & $\mathrm{C} 8$ & Monetary loss & & $\mathrm{C} 19$ & Disappointing others \\
\hline & C9 & Career damage & Fear of & $\mathrm{C} 20$ & Debt \\
\hline & $\mathrm{C} 10$ & Bankruptcy & loneliness & $\mathrm{C} 21$ & $\begin{array}{l}\text { Losing reputation in the } \\
\text { professional network }\end{array}$ \\
\hline & $\mathrm{C} 11$ & Crisis & & & \\
\hline
\end{tabular}


Table 6. A 5-point scale for rating influences between fears of failure

\begin{tabular}{ll}
\hline Corresponding scores & Linguistic terms \\
\hline 0 & No influence \\
1 & Low influence \\
2 & Medium influence \\
3 & High influence \\
4 & Very high influence \\
\hline
\end{tabular}


Table 7. Values of D, R, D+ R, D-R of aspects and criteria.

\begin{tabular}{lrrrrr}
\hline Aspects & Criteria & $\mathrm{D}(\mathrm{Sum})$ & $\mathrm{R}(\mathrm{Sum})$ & $\mathrm{D}+\mathrm{R}$ & \multicolumn{1}{l}{$\mathrm{D}-\mathrm{R}$} \\
\hline Fears related to the procedure & & $\mathbf{4 . 0 1 1 8 6 4}$ & $\mathbf{3 . 9 7 9 0 8 1}$ & $\mathbf{7 . 9 9 0 9 4 5}$ & $\mathbf{0 . 0 3 2 7 8 3}$ \\
& $\mathrm{C} 1$ & 2.450856 & 2.818515 & 5.269371 & -0.36766 \\
$\mathrm{C} 2$ & 2.621703 & 2.636791 & 5.258494 & -0.01509 \\
& $\mathrm{C} 3$ & 2.308796 & 1.942277 & 4.251072 & 0.366519 \\
& $\mathrm{C} 4$ & 1.615941 & 2.59713 & 4.213072 & -0.98119 \\
& $\mathrm{C} 5$ & 3.24927 & 1.621703 & 4.870972 & 1.627567 \\
& $\mathrm{C} 6$ & 2.037659 & 2.66781 & 4.705469 & -0.63015 \\
Fear of future & & $\mathbf{5 . 0 5 0 7 8 7}$ & $\mathbf{4 . 3 2 5 4 2 2}$ & $\mathbf{9 . 3 7 6 2 0 8}$ & $\mathbf{0 . 7 2 5 3 6 5}$ \\
& $\mathrm{C} 7$ & 3.708922 & 3.351104 & 7.060026 & 0.357819 \\
& $\mathrm{C} 8$ & 4.311847 & 3.804374 & 8.116221 & 0.507473 \\
& $\mathrm{C} 9$ & 3.607522 & 4.516061 & 8.123583 & -0.90854 \\
& $\mathrm{C} 10$ & 4.818115 & 4.230615 & 9.04873 & 0.5875 \\
Environmental fears & $\mathrm{C} 11$ & 3.603428 & 4.147681 & 7.751109 & -0.54425 \\
& & $\mathbf{4 . 8 9 0 7 9 2}$ & $\mathbf{3 . 8 0 1 5 1 9}$ & $\mathbf{8 . 6 9 2 3 1 1}$ & $\mathbf{1 . 0 8 9 2 7 3}$ \\
& $\mathrm{C} 12$ & 1.708976 & 1.705738 & 3.414715 & 0.003238 \\
Fear of loneliness & $\mathrm{C} 13$ & 2.418104 & 1.301298 & 3.719403 & 1.116806 \\
& $\mathrm{C} 14$ & 0.797524 & 1.900124 & 2.697648 & -1.1026 \\
& $\mathrm{C} 15$ & 1.645678 & 1.663122 & 3.3088 & -0.01744 \\
Fear of losing credit & & $\mathbf{4 . 0 6 7 2 9 7}$ & $\mathbf{3 . 8 6 0 6 4 7}$ & $\mathbf{7 . 9 2 7 9 4 5}$ & $\mathbf{0 . 2 0 6 6 5}$ \\
& $\mathrm{C} 16$ & 3.142857 & 6.712857 & 9.855714 & -3.57 \\
Moral fears & $\mathrm{C} 17$ & 4.142857 & 3.142857 & 7.285714 & 1 \\
& & $\mathbf{4 . 1 6 8 5 4 8}$ & $\mathbf{4 . 9 6 1 6 5 4}$ & $\mathbf{9 . 1 3 0 2 0 2}$ & $\mathbf{- 0 . 7 9 3 1 1}$ \\
& $\mathrm{C} 18$ & 4 & 3 & 7 & 1 \\
& $\mathrm{C} 19$ & 3 & 6.5 & 9.5 & -3.5 \\
& & $\mathbf{3 . 1 0 8 6 9 3}$ & $\mathbf{4 . 3 6 9 6 5 8}$ & $\mathbf{7 . 4 7 8 3 5 1}$ & $\mathbf{- 1 . 2 6 0 9 7}$ \\
& $\mathrm{C} 20$ & 3 & 2 & 5 & 1 \\
& $\mathrm{C} 21$ & 2 & 5 & 7 & -3 \\
\hline & & & & &
\end{tabular}

